Research Paper

\title{
Groundwater Recharge Evaluation on Yangok-ri Area of Hongseong Using a Distributed Hydrologic Model (VELAS)
}

\author{
Kyoochul Ha ${ }^{1,2}$, Changhui Park ${ }^{3, *}$, Sunghyun Kim ${ }^{3}$, Esther Shin ${ }^{3}$, Eunhee Lee ${ }^{1}$ \\ ${ }^{1}$ Geologic Environment Division, Korea institute of Geoscience and Mineral Resources (KIGAM), Daejeon 34132, Korea \\ ${ }^{2}$ Department of Mineral E Groundwater Resources, University of Science and Technology (UST) \\ ${ }^{3}$ GeoGreen21 Co., Ltd., Seoul 08376, Korea
}

*Corresponding author : changhui.park@geogreen21.com

\section{ARTICLE INFORMATION}

Manuscript received 3 February 2021

Received in revised form 19 February 2021

Manuscript accepted 21 February 2021

Available online 28 April 2021

DOI : http://dx.doi.org/10.9719/EEG.2021.54.2.161

\section{Research Highlights}

- Groundwater recharge was evaluated using a distributed hydrologic model (VELAS) on daily basis.

- The annual groundwater recharge rates in the past were from 3.6 to $28.2 \%$ with a very large variation and average $14.9 \%$.

- The annual groundwater recharge rates by the RCP 8.5 scenario were projected from $2.8 \%$ to $45.1 \%, 18.2 \%$ on average.

\begin{abstract}
In this study, one of the distributed hydrologic models, VELAS, was used to analyze the variation of hydrologic elements based on water balance analysis to evaluate the groundwater recharge in more detail than the annual time scale for the past and future. The study area is located in Yanggok-ri, Seobu-myeon, Hongseong-gun, Chungnam-do, which is very vulnerable to drought. To implement the VELAS model, spatial characteristic data such as digital elevation model (DEM), vegetation, and slope were established, and GIS data were constructed through spatial interpolation on the daily air temperature, precipitation, average wind speed, and relative humidity of the Korea Meteorological Stations. The results of the analysis showed that annual precipitation was 799.1-1750.8 mm, average $1210.7 \mathrm{~mm}$, groundwater recharge of $28.8-492.9 \mathrm{~mm}$, and average $196.9 \mathrm{~mm}$ over the past 18 years from 2001 to 2018 in the study area. Annual groundwater recharge rate compared to annual precipitation was from 3.6 to $28.2 \%$ with a very large variation and average $14.9 \%$. By the climate change RCP 8.5 scenario, the annual precipitation from 2019 to 2100 was $572.8-1996.5 \mathrm{~mm}$ (average $1078.4 \mathrm{~mm}$ ) and groundwater recharge of $26.7-432.5 \mathrm{~mm}$ (average precipitation 16.2\%). The annual groundwater recharge rates in the future were projected from $2.8 \%$ to $45.1 \%, 18.2 \%$ on average. The components that make up the water balance were well correlated with precipitation, especially in the annual data rather than the daily data. However, the amount of evapotranspiration seems to be more affected by other climatic factors such as temperature. Groundwater recharge in more detailed time scale rather than annual scale is expected to provide basic data that can be used for groundwater development and management if precipitation are severely varied by time, such as droughts or floods.
\end{abstract}

Keywords : groundwater, recharge, VELAS, climate change scenario, water budget analysis

Citation: Ha, K., Park, C., Kim, S., Shin, E., Lee, E. (2021) Groundwater Recharge Evaluation on Yangok-ri Area of Hongseong Using a Distributed Hydrologic Model (VELAS). Korea Economic and Environmental Geology, v.54, p.161-176, doi:10.9719/ EEG2021.54.2.161.

x Journal homepage: http://www.kseeg.org/main.html

This is an Open Access article distributed under the terms of the Creative Commons Attribution Non-Commercial License (http:/creativecommons.org/ licenses/by-nc/3.0) which permits unrestricted non-commercial use, distribution, and reproduction in any medium, provided original work is properly cited. pISSN 1225-7281; eISSN 2288-7962/C2021 The KSEEG. Printed by Hanrimwon Publishing Company. All rights reserved. 


\title{
연구논문
}

\section{분포형 수문모형(VELAS)을 이용한 홍성 양곡리 일대 지하수 함양량 평가}

\author{
하규철 ${ }^{1,2} \cdot$ 박창희 $^{3, *} \cdot$ 김성현 ${ }^{3} \cdot$ 신에스더 ${ }^{3} \cdot$ 이은희 ${ }^{1}$ \\ 1한국지질자원연구원 지질환경연구본부 \\ 2과학기술연합대학원대학교 광물·지하수자원학과 \\ 3 (주)지오그린 21
}

*책임저자 : changhui.park@geogreen21.com

\begin{abstract}
요 약
본 연구는 과거와 미래의 연 단위보다 상세한 일단위 지하수 함양량을 평가하기 위해, 분포형 수문모형중의 하나인 VELAS를 이용하여 물수지에 근거한 수문요소별 변동을 분석하고자 하였다. 가뭄에 매우 취약한 충남 홍성군 서부면 양곡리 일대 소유역 을 대상으로, VELAS의 입력자료인 수치표고모델, 식생도, 경사도 등의 공간특성자료를 구축하였고, 기후자료는 기상청의 일별 대기온도, 강수, 평균풍속, 상대습도 등의 자료를 공간적으로 보간하였다. 연구지역의 과거 2001년부터 2018년까지 18년 동안 일단위 물수지 분석결과, 연간 강수량은 799.1 1750.8 mm로 평균 $1210.7 \mathrm{~mm}$ 이고, 지하수 함양량은 $28.8 ~ 492.9 \mathrm{~mm}$ 로 평균 $196.9 \mathrm{~mm}$ 로 분석되었다. 연 강수량 대비 지하수 함양률은 최소 $3.6 \%$ 에서 최대 $28.2 \%$ 로 변동폭이 매우 크고, 평균 함양률은 $14.9 \%$ 였다. 미래 기후변화 RCP 8.5시나리오에 의한 2019년부터 2100년까지의 일단위 물수지 분석결과, 연간 강수량은 $572.8 ~ 1996.5 \mathrm{~mm}$ (평 균 $1078.4 \mathrm{~mm}$ )이고, 지하수함양량은 $26.7 \sim 432.5 \mathrm{~mm}$, 평균 $174.6 \mathrm{~mm}$ (평균 강수량의 $16.2 \%$ )로서 과거보다 다소 증가하였다. 미 래 연간 지하수 함양률은 최소 $2.8 \%$, 최대 $45.1 \%$, 평균 $18.2 \%$ 로 분석되었다. 물수지를 구성하는 요소들은 강수량과의 상관성이 잘 나타나며, 일단위보다는 연단위로 갈수록 그러한 상관성이 뚜렷했다. 다만, 증발산량은 강수량보다는 기온 등 다른 기후요소 에 더 영향을 받는 것으로 보인다. 본 연구를 통해 산정된 연단위 보다 상세 시간 단위에서의 지하수함양량은 가뭄 또는 홍수 등 시기별로 강수량 변동이 심한 경우 지하수개발과 관리에 활용될 수 있는 기초자료를 제공할 수 있을 것으로 기대된다.
\end{abstract}

주요어 : 지하수, 함양량, VELAS, 기후변화 시나리오, 물수지 분석

\section{1. 서 론}

지하수 함양은 강수가 지표로 침투하여 지하수면까지 도달하여 궁극적으로 지하수 부존량을 증가시키는 과정 이다. 지하수 함양에 의하여 지하수위가 상승하고, 그에 따라 이용가능한 지하수량도 많아진다고 할 수 있다. 우 리나라에서는 지하수 함양량에 일종의 안전율인 약 $70 \%$ 정도를 적용하여 개발가능량으로 산정하여 적용하고 있 다(Ministry of Land and Transport, 2017). 이 안전율은 연 기준으로 평년대비 10 년 빈도 가뭄시 강수량을 적용 할 때의 값이다.

국내에서 지하수 함양량 또는 강수량 대비 함양률을 산 정하는 방법은 지하수위 강하곡선법(Choi and Ahn, 1998; Kim et al., 2004), 지하수위 변동법(Healy and Cook, 2002; Koo and Lee, 2002; Park, 2012; Yoon et al., 2016), 기 저유출 분리법(Park, 1996; Bae and Kim, 2006), 물수지 분석 방법(Park et al., 1999; Shin et al., 2016) 등 다양하다.

물수지 분석은 강수와 지표유출, 지하수 함양, 증발산 등 물순환 과정을 이루는 요소들에 대한 평가과정으로
이해할 수 있다. 강수가 발생하게 되면, 일부는 식생에 의해 차단이 되고, 땅에 떨어진 강수는 지표에서의 직접 유출과 지하로의 침투가 일어나게 된다. 지하로 침투한 물은 토양수분함량을 증가시키고, 다시 지표로 흘러나오 거나 그 외는 지하수면까지 도달하여 지하수로 함양이 된다. 지표에 떨어진 강수는 증발(Evaporation) 또는 식생 에 의한 증산(Transpiration)에 의해 다시 대기로 돌아가 는 증발산 과정을 겪는다.

이러한 일련의 과정을 수학적 모형을 가지고 수문순환 요소별로 정량적으로 계산할 수 있는데, 이를 수문모형 이라고 하고, 모의방법 및 공간적 특성 반영여부에 따라 집중형 수문모형(Lumped hydrological model)과 분포형 수문모형(Distributed hydrological model)으로 구분할 수 있다(Jang et al., 2013). 집중형 수문모형은 하나의 유역 에서 단일 강우(평균 강우), 단일 공간입력 자료를 이용 하여 주로 경험적 지배방정식을 이용하여 각 수문요소별 수량을 결정한다. 반면에 분포형 수문모형은 유역을 다수 의 그리드 또는 셀 단위로 나누고, 수치지형 자료와 다양 한 물리적 특성치를 입력하고, 물리적 기반의 지배방정 
식을 이용한다. 따라서, 분포형 수문모형은 유역 내부의 어느 점에서든지 유출모의가 가능하며, 인접 격자들 간 의 강우, 침투 등의 산정값에 따라 물수지를 계산할 수 있다.

본 연구는 분포형 수문모형을 이용하여 지하수 함양량 을 연단위보다도 더 상세한 시간단위에서 평가하기 위한 목적을 가지고 진행되었다. 기존의 많은 연구들은 지하 수 함양량을 평가하는데 주로 연단위로 평가가 이루어졌 다. 그러나, 이러한 연단위 지하수 함양량 산정 결과는 강수가 여름에 집중적으로 발생하고, 강수가 없는 시기 에 지하수 사용이 많아지는 우리나라의 현실에서는 적용 에 한계가 있다. 특히, 지하수 관리를 위해 가뭄이나 시 기별 지하수 함양량 변동을 고려해야 하는 경우에는 연 단위보다 더 상세한 시간단위에서의 지하수 함양량 평가 가 이루어져야 한다. 따라서, 본 연구에서는 분포형 수문 모형을 이용하여 물수지에 기반한 과거의 지하수 함양량 평가 및 변동성을 분석하고자 하였다. 또한, 미래의 지하 수 함양량 변동을 평가하기 위해 기후변화 시나리오에 근거한 물수지 분석을 수행하였다.

그동안 국내외에서는 다양한 분포형 수문모형이 개발 되었으며, 그 중에 잘 알려진 모델은 Table 1과 같다. SWAT(Soil and Water Assessment Tool) 모형은 미국 농 무성(USDA Agricultural Research Service, ARS)이 개발 한 유역 수문모형으로, 전체 유역의 수문분석을 위해 수 문반응단위(Hydrological Response Unit, HRU)별로 증발 산, 지표유출, 기저유출 등을 계산하고, 이를 통해 장기 간의 연속적인 하천유량을 산정한다(Arnold et al., 1999; Neitsch et al., 2002). SWAT-K는 한국건설기술연구원이 위의 SWAT 모형을 국내 유역특성 및 물 공급 특성에 맞 게 개선하고, 3 차원 지하수유동 모형인 미국 지질조사소
(USGS, US Geological Survey)에서 개발한 MODFLOW 와 도시유출해석 모형인 SWMM(Storm Water Management Model, 도심지 배수관망 모형)과의 결합을 이룬 모형이 다(KICT, 2007). SWAT-K 모형은 개발되고 나서 설마천 유역, 충주댐 유역 등 다양한 지역에 적용되었으며(Kim et al., 2007; Kim et al., 2009), 최근에는 지하수 기초조 사 등 다양한 조사 및 연구에 활용되고 있다. MIKE SHE 는 강우, 차단, 증발산, 침투량에 대한 고려와 2차원 지 표수 및 지하수 유출을 포함한 전체 수문순환을 모의할 수 있는 모형이다. 1977년부터 영국, 프랑스, 덴마크의 연 구기관들이 컨소시엄을 구성하여 SHE(Système Hydrologique Européen)을 개발한 이후, DHI(Danish Hydraulic Institute) 에서 지속적인 연구개발을 통해 현재 MIKE SHE라는 이 름으로 상용화되었다(Abbot et al., 1986). 이 모델은 지 표수 및 지하수와 관련된 광범위한 수자원 및 환경 문제, 특히 지하수 취수로 인한 지표수 영향, 지하수 및 지표 수의 연계이용, 습지 관리 및 복원에 대한 분석, 수자원 및 유역관리 등 다양한 분야에서 활용되고 있다(Kim et al., 2007; Kim et al., 2020). $\mathrm{Vflo}^{\mathrm{TM}}$ 모형는 물리적 기반 의 분포형 강우-유출 과정의 해를 구하기 위해 공간적으 로 유한요소법, 시간적으로는 유한차분 음해법을 사용하 고 지표유출 산정을 위하여 운동파 방정식(Kinematic wave equation)을 사용한다(Vieux, 2004). 국내에서는 주로 강 우-유출과 관련된 홍수 모의에 활용되고 있다(Park and Kang, 2006). 이 밖에도 지표수, 지하수, 농업 분야 등에 서 그 특성을 보다 잘 구현해 내기 위해 연구기관 또는 연구자별로 다양한 모델들이 개발 및 보급되고 있다.

본 연구에서 사용된 VELAS(VEgetation-LAnd coverSoil water dynamics) 모형은 미국 미주리 주립대학교

Table 1. Comparisons of the distributed hydrological models

\begin{tabular}{|c|c|c|c|}
\hline Model & Features & Developer & References \\
\hline $\begin{array}{l}\text { SWAT (Soil and Water } \\
\text { Assessment Tool) }\end{array}$ & $\begin{array}{c}\text { Calculation based on each } \\
\text { HRU(Hydrological Response Unit) of } \\
\text { land use and soil and topography }\end{array}$ & $\begin{array}{c}\text { Agricultural Research } \\
\text { Service, US Department of } \\
\text { Agriculture (USDA ARS) }\end{array}$ & $\begin{array}{l}\text { Neitsch et al.(2002), } \\
\text { Arnold et al.(1999) }\end{array}$ \\
\hline SWAT-K & $\begin{array}{l}\text { Improvement of SWAT model for } \\
\text { Korean characteristics }\end{array}$ & $\begin{array}{c}\text { Korea Institute of } \\
\text { Construction and } \\
\text { Transportation (KICT) }\end{array}$ & $\begin{array}{l}\text { KICT(2007), Kim et } \\
\text { al.(2008), Kim et } \\
\text { al.(2009) }\end{array}$ \\
\hline $\begin{array}{l}\text { MIKE-SHE(System } \\
\text { Hydrologique European) }\end{array}$ & $\begin{array}{l}\text { A physically-based distributed tracking } \\
\text { model that simulates all hydrological } \\
\text { components of water cycle }\end{array}$ & $\begin{array}{l}\text { Abbott et al.(1986), } \\
\text { DHI(1999) }\end{array}$ & $\begin{array}{l}\text { Abbott et al.(1986), } \\
\text { Kim et al.(2007), Kim } \\
\text { et al.(2020) }\end{array}$ \\
\hline $\mathrm{Vflo}^{\mathrm{TM}}$ & $\begin{array}{l}\text { Physically-based distributed model used } \\
\text { mainly for flood estimation }\end{array}$ & Oklahoma University & $\begin{array}{l}\text { Vieux(2004), Park and } \\
\text { Kang(2006) }\end{array}$ \\
\hline $\begin{array}{l}\text { VELAS(Vegetation, land } \\
\text { cover, and soil water } \\
\text { dynamics) }\end{array}$ & $\begin{array}{l}\text { A simple hydrologic feedback model to } \\
\text { simulate daily responses of hydrologic } \\
\text { processes under various conditions of } \\
\text { vegetation, land cover, and soil in a } \\
\text { fully-distributed manner }\end{array}$ & $\begin{array}{c}\text { University of Missouri- } \\
\text { Kansas City, Kongju National } \\
\text { University, Korea Institute of } \\
\text { Geoscience and Mineral } \\
\text { Resources (KIGAM) }\end{array}$ & Park et al.(2013) \\
\hline
\end{tabular}


(University of Missouri - Kansas City), 공주대학교, 한 국지질자원연구원이 공동으로 개발한 완전분포형 지표수 -지하수 통합 유동 모델이다. VELAS는 식물 성장을 고 려한 토지피복의 변화와 그에 따른 토양 수분의 변화를 정량적으로 모사함으로서 보다 실제적인 지표유출, 증발 산 및 함양량 추정이 가능하며 서브셀(Sub-Cell) 개념을 도입하여 단일 격자내 토지피복변화에 따른 물수지 변화 의 모사가 가능하다. 모델의 입력 자료는 단순화되어 쉽 게 취득 가능한 식생, 토지피복, 토양, 지형 및 일단위 기 후(강수량, 기온, 상대습도, 풍속)자료 만으로 모델링이 가능하고 $\mathrm{ArcGIS}$ 의 제작사인 ESRI의 래스터(ESRI ASCII Raster)형을 도입하여 자료의 전처리와 타 모델과의 자료 교환이 용이한 장점이 있다.

\section{2. 연구방법}

\subsection{VELAS 모형}

본 연구에서는 연구지역의 지하수함양량 평가를 위해 앞서 언급한 분포형 수문모형인 VELAS 모형을 적용하 였다. VELAS 모형은 5가지 수문현상(차단, 지표유출, 증 발산, 토양수분변화, 지하수함양)의 정량적 계산을 위하 여 이에 따른 하위 모델들을 포함하며, 지하수 유동 모사 에 있어서는 미국 지질조사소(USGS)의 MODFLOW(Harbaugh et al., 2000)와 순차적으로 연동된다. VELAS 모형의 물 의 이동에 따른 수문현상과 물수지 계산의 개념은 강수 에서 시작하여 지표를 거쳐 지하수에 도달하는 일반적인 물의 이동경로를 따르는 하향식 모델이며, 일단위 토양 수분 변화를 계산하여 토양내 수분의 변화가 다른 물수 지 요소들에 미치는 영향을 함께 계산되도록 설계되어 있다. 따라서, 식물의 생장에 따른 지표환경 및 증발산의 변화도 고려할 수 있으므로, 보다 정밀한 물수지를 계산 해 낼 수 있다(KIGAM, 2012).

VELAS 모형에서 하나의 셀에 대한 일단위 물수지를 계산하는 과정은 Figure 1에 요약되어 있으며, 각 수문요 소별 산정 방법은 Park et al.(2013)을 참조할 수 있다. 여 기서는 VELAS 모형의 핵심이 되는 수식을 중심으로 모 델을 구현하는 과정을 간단하게 제시하였다. Figure 1에 서 나타낸 바와 같이 VELAS 모형에서는 (1) 강수량, (2) 차단량, (3) 증발산량, (4) 지표유출량, (5) 토양수분 변화, 그리고, (6) 지하수 함양량 산정의 총 6단계의 계산과정 을 거친다. 토양층 또는 식물의 근권(뿌리층)으로 들어간 침투량은 아래의 식(1)로 계산이 된다.

$$
I N F_{i}=P_{i}-I_{i}-R O_{i}
$$

여기서 $I N F$ 는 침투량(Infiltration), $P$ 는 강수량(Precipitation),

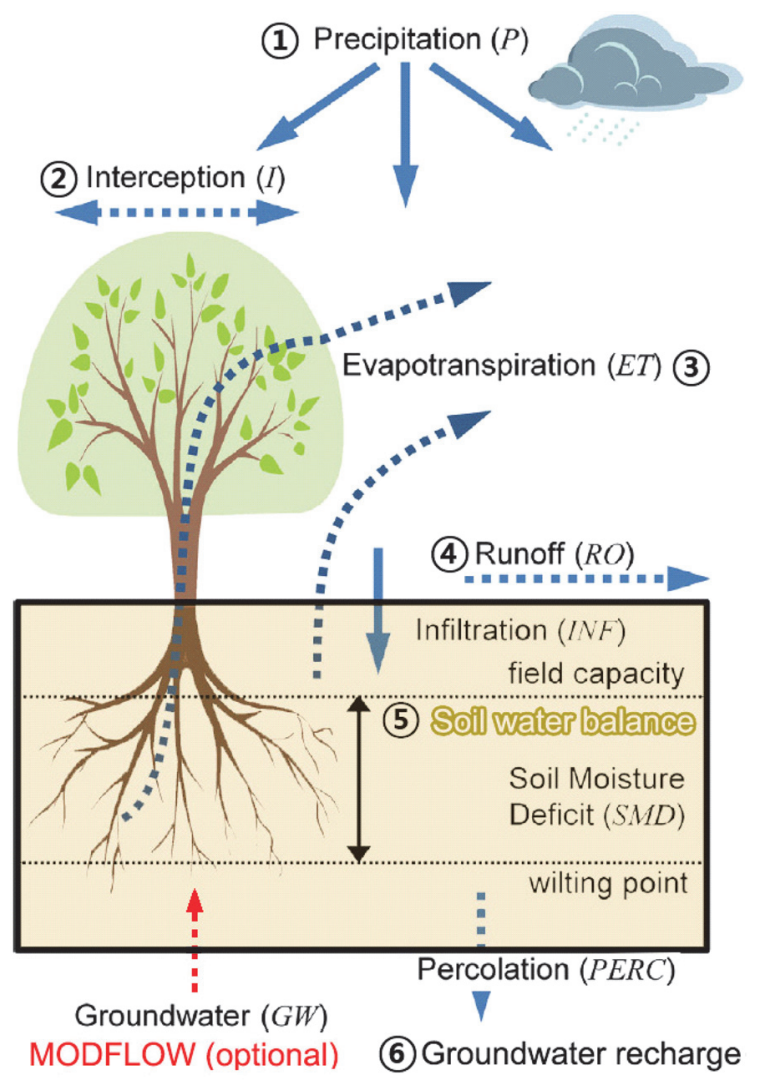

Fig. 1. Modeling concept and work flow of VELAS model, which are modified from Park et al.(2013).

$I$ 는 차단량(Interception), $R O$ 는 직접유출량(Runoff), 그리 고, $i$ 는 시간(일)이다. 토양층 내에서 물수지는 다음 식 (2)에 의하여, 토양수분결핍량(soil moisture deficit), SMD 와 증발산량(Evapotranspiration), ET, 그리고, 지하수로부 터 공급량(Groundwater supply), $G W$ 으로 나타낼 수 있다.

$S M D_{i}=S M D_{i-1}-I N F_{i}+E T_{i}-G W_{i}$

또한, 토양층 또는 식물의 근권을 통과해서 지하수면 까지 도달되는 양인 침루량(Percolation), $P E R C$ 는 위의 식(2)에서 산정된 토양수분결핍량, $S M D$ 가 아래와 같이 음수일 경우에만 발생한다고 가정한다. 즉, 토양층 또는 식물의 근권에서 토양수분결핍이 있는 경우 $\left(S M D_{i}>0\right)$ 에 는 지하수로 함양되지 않고, 토양층 내에 저장되는 것으 로 모의된다.

$$
P E R C_{i}=\left|S M D_{i}\right| \quad \text { if } \quad S M D_{i}<0
$$

VELAS 모형에서는 선택적으로 미국 지질조사소(USGS) 의 MODFLOW(Harbaugh et al., 2000)와 연동될 수 있는 
데, 물수지에 의해 계산된 지하수 함양량이 MODFLOW 의 입력자료로 활용된다. 지하수 함양에 따라 지하수위가 상승하면, 경우에 따라 토양층 및 식물의 근권에서 식(2) 에 의하여 지하수공급량, $G W$ 값으로 제공된다. 이렇게 지하수가 상부로 공급이 되면, 토양층 또는 식물의 뿌리 로부터 증발산이 촉진되게 되는데, 이 경우 증발산량이 재산정 된다.

\section{2. 연구지역}

연구지역은 충남 홍성군 서부면 양곡리 일대로서, 가 뭄이 빈번하게 발생하여 공공 지하수 개발이 많이 이루 어진 지역이다. 특히, 2018년 여름, 7월과 8월에는 평년 의 $10 \%$ 에도 미치지 않는 강수량 때문에 주변 저수지도 말라서 논에 공급할 물이 부족해지자, 약 $4 \mathrm{~km}$ 떨어진 홍성호로부터 비상관로를 통해 물을 공급받을 수밖에 없 는 지경에 이르렀다. 그런데, 홍성호의 물은 서해안으로 빠져나가는 하천수를 가두고, 해수가 하천을 따라서 흘 러 들어오는 것을 막아서 담수화 되는 과정을 겪고 있었 기 때문에, 아직은 염도가 높아서 관개용수로서 활용하 기에는 위험성이 있었다. 따라서, 공급되는 관개용수에 대한 염도를 점검하고, 농도 $1250 \mathrm{ppm}$ 을 넘어서면 물공 급을 중단하였다. 다행히 8 월 말에 충분한 양의 강수가 내리자 비로소 가뭄이 해갈되었지만, 이러한 가뭄 상황 이 몇 주간 더 지속되었다면, 그야말로 농업용수는 모두 고갈되어 버리고, 생활용수도 부족하게 되어 식수를 멀 리서부터 운반해 올 상황이었다.

이와 같이 연구지역은 물에 대한 스트레스가 심한 곳 으로, 최근에 기존 관정을 연계하여 가뭄시 활용가능한
지하수량을 확보·공급하기 위해 관정연계시스템(Well network system)이 개발되고 있는 지역이다. 이와 같은 관정연계시스템 적용을 위해서는 무엇보다도 대상지역의 물수지와 지하수함양량을 평가하는 것이 중요하다. 그러 나, 그동안 이 지역에서 이루어진 물수지 또는 지하수함 양량 평가는 연단위로 이루어져 시기별로 가뭄에 대한 대처와 지하수 관리를 하는데 한계가 있었다(MCT et al., 2005; KIGAM et al., 2018). 따라서, 본 연구는 앞서 언 급하였듯이, 2018년 경우와 같은 여름철 가뭄, 또는 일정 한 시기 동안 발생하는 가뭄에 대응하는 물공급 체계와 수자원 관리를 위해 연단위가 아닌 보다 상세한 시간단 위에서의 물수지와 지하수 함양량 평가를 수행하고자 하였다.

연구지역은 해발고도 $100 \mathrm{~m}$ 이하의 구릉성 산지와 비 교적 평탄한 농경지로 구성되어 있다. 토지이용은 산림 지역이 $189.1 \mathrm{ha}(66.7 \%)$ 를 차지하고, 논농사 지역이 49.5 $\mathrm{ha}(17.5 \%)$, 밭농사 지역이 $37.7 \mathrm{ha}(13.3 \%)$, 그 외의 거주 지, 도로, 수류 등이 $6.94 \mathrm{ha}(2.4 \%)$ 를 차지하고 있다. 우 리나라 전형적인 농촌의 모습으로, 산으로 둘러싸인 평 탄한 분지에서 논농사와 밭농사가 이루어지고 있다. 밭 작물로는 깨, 고추, 수수 등이 주를 이루고 있고, 최근 들 어 콩, 호박, 마늘, 파, 대추 등 재배 작물의 종류가 다양 해지고 있다(Figure 2(a)). 시추조사 결과, 토양층 두께는 6.0 7.5 m정도이고, 그 아래로 풍화암이 2.0 22.3 m두께 로 분포하고 있으며, 그 아래에 편암 또는 편마암이 분 포하고 있다. 1963년 발간된 지질도폭에 따르면, 선캠브 리아기의 결정편암계와 편마암, 이를 신생대 제4기 충적 층이 부정합으로 덮고 있는 것으로 조사되었다(Lee and Kim, 1963). 2014년 이루어진 지질조사에서는 좌우로 궁

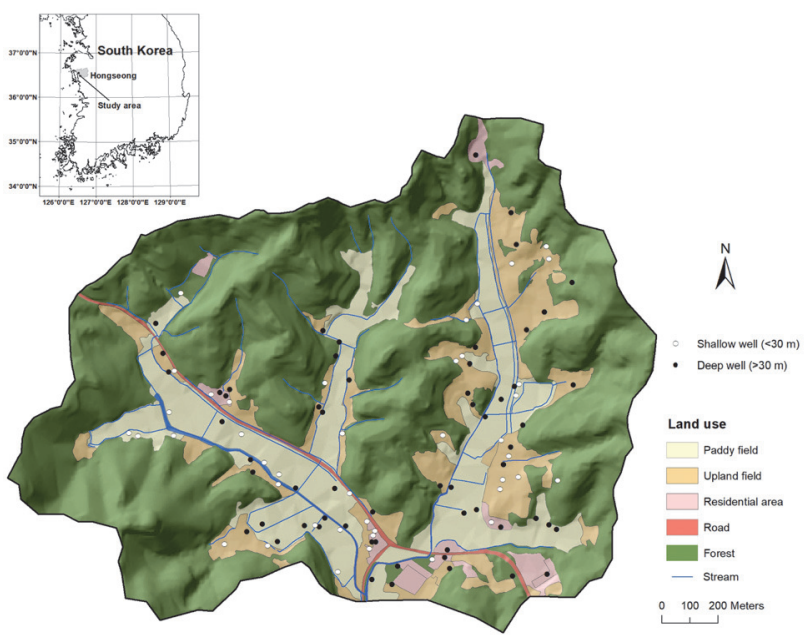

(a)

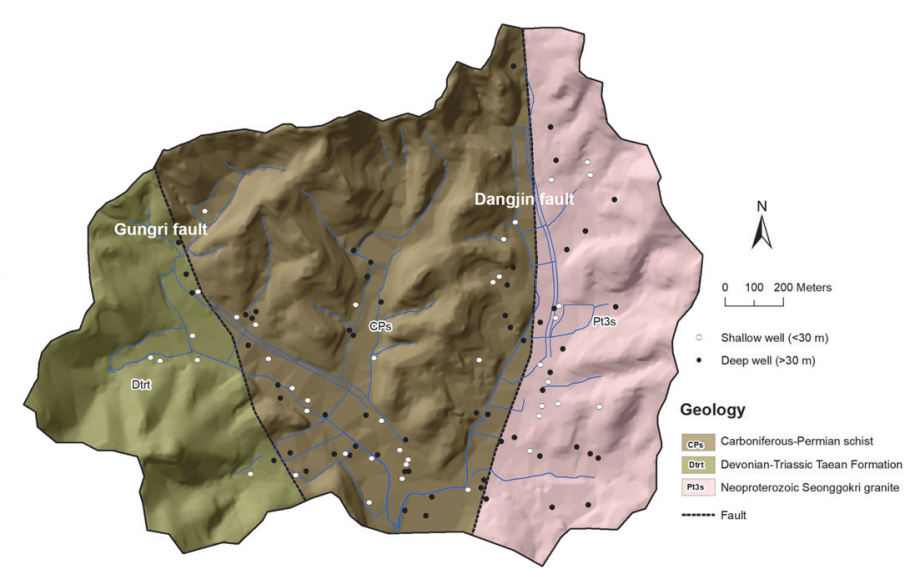

(b)

Fig. 2. Land use (a) and geology (b) with the existing wells of the study area. 
리단층과 당진단층이 신원생대 성곡리 화강암, 석탄기-페 름기 편암, 데본기-트라이아스기 태안층을 서로 구분하고 있다(Figure 2(b)). 신원생대 성곡리 화강암은 우백질 화 강암으로 주로 구성되며, 괴상 혹은 미약한 엽리를 보이 고, 석탄기-페름기 편암은 흑운모-석영 편암과 변성사암 으로 구성된다. 연구지역의 서쪽에 분포하는 데본기-트라 이아스기 태안층은 변성사암 및 천매암으로 구성되며, 괴 상 혹은 점이층리를 보이는 석영질 변성사암이 우세하게 발달한다(Kim et al., 2014).

홍성군으로부터 수집된 지하수 이용현황을 살펴보면, 이 지역에는 총 107 개소의 지하수 이용시설이 있고, 이 중 신고시설은 103 개소, 허가시설은 4 개소가 있다. 깊이 별로는 $30 \mathrm{~m}$ 심도이하의 충적층 관정이 43 개이고, $30 \mathrm{~m}$ 심도 이상 암반대수층을 대상으로 개발된 관정은 64 개이 다. 연구지역은 지하수 의존도가 높기 때문에 단위면적 당 개발공수가 37.8 개 $/ \mathrm{km}^{2}$ 로 전국 평균 16.3 개 $/ \mathrm{km}^{2}$ 에 비하여 2배 이상 높다(ME and K-water, 2019).

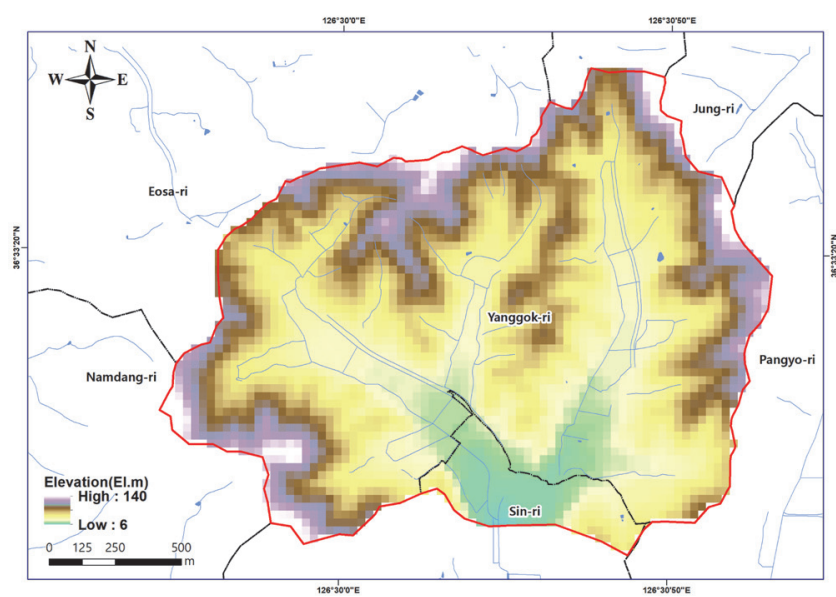

(a)

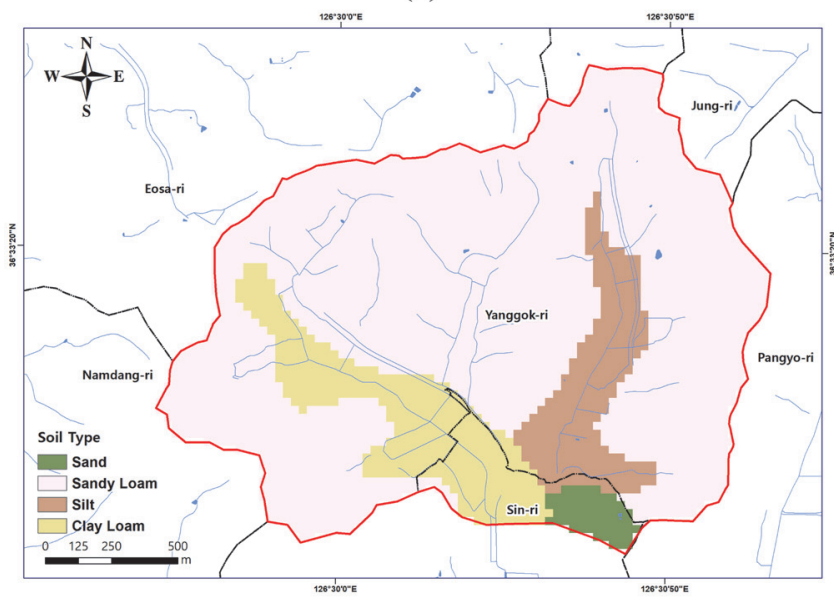

(c)

\section{3. 입력자료 구축}

VELAS 모형을 위한 지표 식생도는 각 격자에 분포하 는 식물을 나타내는 것으로 토지피복도와 임상도를 이용 하여 간접적으로 생성하였다. 국가수자원관리종합정보시 스템(WAter resources Management Information System, www.wamis.go.kr)에서 제공하는 토지피복도는 LANDSAT 자료를 기반으로 7 분류로 구성되어 있고, 산림지역은 수 종의 구분 없이 하나의 분류로 통일되어 있다. 계절의 변 화에 따른 지표 식생의 변화와 그와 연계되는 토지피복 특성 및 증발산량의 계절적 변화를 모델에 반영하기 위 해서는 산림지역을 나무의 수종에 따라 재분류할 필요가 있다. WAMIS에서 제공하는 임상도는 산림지역에 분포 하는 나무의 수종에 따라 침엽수림, 활엽수림, 혼효림으 로 구분하여 도시하고 있다. 이를 이용하여 토지피복도 의 산림 영역을 임상도의 세분된 산림 분포로 치환하여 VELAS 모형에서 요구하는 식생도로 생성한 후 모델에 포함시켰다. 토양도는 농업진흥청이 토양환경정보시스템

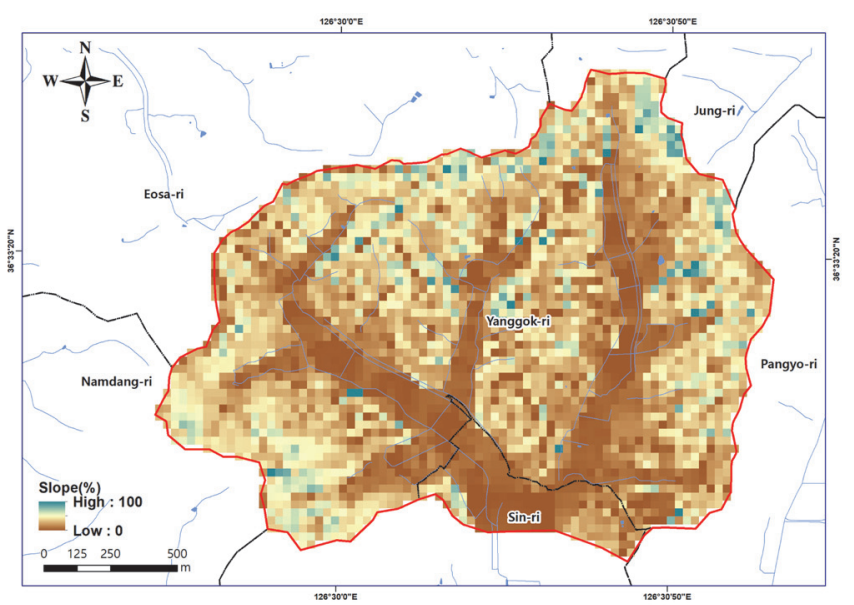

(b)

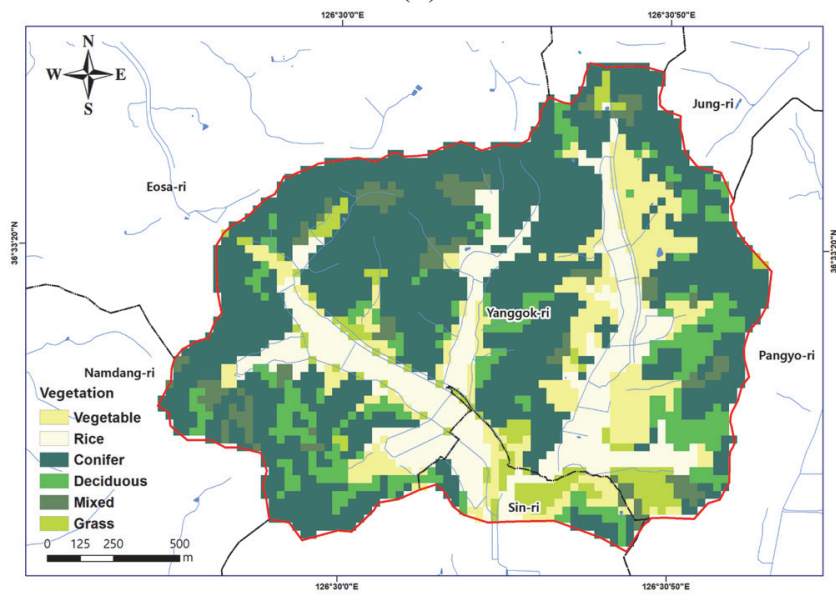

(d)

Fig. 3. Spatial input data preparation for the VELAS model in the study area, (a) DEM, (b) slope, (c) soil, and (d) vegetation. 
(KSIS, 2019)을 통해 제공하는 1:25000 축척의 벡터형 토 양도를 래스터(Raster)로 변환하였다. 수치고도모델(DEM: Digital Elevation Model)은 미항공우주국(National Aeronautics and Space Administration: NASA)에서 셔틀레이다미션 (SRTM: Shuttle Radar Topography Mission)을 통해 제공 하는 SRTM 분석자료 버전 4.1(Processed SRTM Data version 4.1)을 이용하였다(Jarvis et al., 2008). 지표유출 량은 지형의 경사를 반영하여 계산하여야 하며, 이때 필 요한 경사분석도는 수치고도모델을 이용하여 작성하였다.

VELAS 모형의 입력 자료로서 기후자료는 연구지역 주 변에 종관 기상관측소의 부재로 인하여 다음과 같은 절 차로 기상자료를 공간보간하여 값을 추출하였다. 기상자 료는 유역의 물수지 분석결과에 직접적인 영향을 미치는 중요한 인자 중 하나이지만, 자료의 형태가 각 기상관측 소의 관측점에서 측정한 포인트 형식의 시계열 자료가 대부분이므로 분포형 모델에 적용할 때에는 공간보간을 실시한 후 이용하는 것이 일반적이다. 그러므로 각 기후 요소별로 적합한 공간 보간법을 적용하여 분포형 자료를 생성하는 것이 물수지 분석 결과의 정확성과 신뢰성을 높일 수 있다.

본 연구에서는 기상청에서 관리하는 153 개의 기상관측 소(종관, 북한)의 2001 2018년까지 일별 평균기온, 최고 기온, 최저기온, 강수, 평균풍속, 상대습도 자료를 수집하 여 이용하였는데, 연구지역의 기상입력자료 구축에 가장 큰 영향을 미치는 관측소는 서산, 보령, 홍성 관측소이다 (KMA, 2018). 여러 기후요소 중 기온 관측 자료는 증발 산에 큰 영향을 미치는 요소로 각 관측소의 위치 및 해 발고도와 측정 장비의 높이에 따른 영향을 포함하고 있 으므로 고도에 따른 기온감률을 고려한 공간보간을 실시 하여야 한다(Lee et al., 2010). 각 기온 요소별 고도 변 화에 따른 기온 감률 보정은 식 (4) (7)로 이루어지며, 여기서 기온 변화에 따른 식생의 변화는 고려하지 않는다.

$$
\begin{aligned}
|\tau|_{\text {avg }} & =0.00688+0.0015 \cos (0.00172(i-60)) \\
|\tau|_{\max } & =0.00708+0.003 \cos (0.00172(i-120)) \\
|\tau|_{\min } & =0.00695+0.0013 \cos (0.00172(i-30))
\end{aligned}
$$

$|\tau|_{\text {avg }},|\tau|_{\max },|\tau|_{\min }$ : 각각 평균, 최저, 최고기온감률 $i$ : 연중날짜(1 365)

$$
T=T_{i} \pm E L \times|\tau|
$$

$T$ : 보정된 기온

$$
\begin{aligned}
& T_{i}: i \text { 일의 기온 } \\
& E L: \text { 관측점 해발고도 }(\mathrm{m})
\end{aligned}
$$

기온 감률 보정과 공간보간은 파이썬(Python)과 ArcGIS 의 지오프로세싱(Geoprocessing) 도구를 이용하여 수행하 였다. 먼저 각 관측소의 관측된 기온 값을 식 (4) (7)을 이용하여 해발고도 $0 \mathrm{~m}$ 에서의 기온값으로 보정한 후 크 리깅(Kriging) 기법을 적용하여 공간보간을 실시하였다. 이후 공간보간된 기온 분포자료를 연구지역을 기준으로 추출하였다. 최종적으로 다시 기온 감률식을 역으로 적 용하여 실제 지형의 고도에 따른 기온분포도를 작성하였다. 기상자료는 반-베리오그램(Semi-variogram) 분석을 통 해 각 기상자료별 최적모델을 선택한 후 크리깅(Kriging) 공간보간 기법을 적용하였다. 풍속자료도 관측소별로 서 로 다른 고도에서 측정된 자료이므로, 일반적으로 평균 풍속은 고도가 높아질수록 증가되므로 Allen et al.(1998) 이 제안한 높이에 따른 풍속 보정식 식 (8)을 이용하여 지상 $2 \mathrm{~m}$ 높이에서의 풍속으로 보정 후 크리깅(Kriging) 기법으로 보간하였다.

$$
u_{2}=u_{z} \frac{4.87}{\ln (6.87 z-5.42)}
$$

$u_{2}$ : 높이 $2 \mathrm{~m}$ 에서의 풍속

$u_{z}:$ 높이 $\mathrm{z}$ m에서의 풍속

공간 보간된 기상자료는 격자크기 $1 \times 1 \mathrm{~km}$ 의 ASCII형 식으로, 격자의 크기와 연구지역 영역과 서로 교차되어 공간적으로 인접하는 셀영역을 추출하고, 평균을 산출하 였다. VELAS 모형은 ESRI사의 래스터(Raster)형식을 도 입하여 자료를 처리하므로 입력 자료는 분석 GIS환경에 맞게 $30 \times 30 \mathrm{~m}$ 격자크기로 변환하였다.

또한, 연구지역에서 지하수위는 지표하 $0.67 \sim 16.53 \mathrm{~m}$ 에 분포하고, 평균적으로 $4.6 \mathrm{~m}$ 로 깊게 형성되어 있다 (KIGAM et al., 2018). 따라서, 본 연구에서는 한번 지하 수로 함양된 물이 다시 상부로 공급되어 증발산에 이용 되기는 어려울 것이라는 판단 하에 MODFLOW 연계 모 사는 진행하지 않았다.

\section{4. 기후변화 시나리오}

본 연구에서는 과거 2001 2018년까지의 일단위 지하 수 함양량을 평가하였고, 미래의 지하수 함양량 변화는 기상청에서 제공하는 기후변화 시나리오에 따라서 평가 하였다. 기상청은 IPCC 5차 평가보고서에서 제시된 온실 가스 배출 시나리오를 RCP 2.6/4.5/6.0/8.5라는 4개 시나 리오에 따라 한반도 및 각 지역별 기후변화 전망을 시나 
리오별로 기후정보포털(http://www.climate.go.kr)을 통해 배포하고 있다. RCP 2.6은 인간 활동에 의한 영향을 지 구 스스로가 회복 가능한 경우이고, RCP 4.5는 온실가스 저감 정책이 상당히 실현되는 경우, RCP 6.0 은 온실가스 저감 정책이 어느 정도 실현되는 경우, $\mathrm{RCP} 8.5$ 는 현재 추세(저감없이)로 온실가스가 배출되는 경우의 시나리오 이다. 본 연구에서는 현재 상태대로 온실가스가 배출되 는 경우의 시나리오인 RCP 8.5에서 VELAS 모형을 모 의하기 위해 필요한 기상요소인 강수량, 기온, 상대습도, 풍속 자료를 수집하였다. 그리고, 모든 기상요소에 대하 여 $12.5 \mathrm{~km}$ 의 해상도를 가지는 자료로 2019년부터 2100 년까지 예측된 자료를 획득하였으며, VELAS 모형은 입 력 자료의 형태. 격자크기, 공간정보가 같아야 하므로 $30 \times 30 \mathrm{~m}$ 격자크기로 변환하여 적용하였다.

\section{3. 결과 및 고찰}

\section{1. 과거 물수지 분석 결과(2001년 2018년)}

Table 2와 Figure 4는 과거 2001년부터 2018년까지 18 년 동안 연도별 물수지 분석 결과를 나타낸 것이다. 연간
강수량은 799.1 1750.8 mm로 평균 $1210.7 \mathrm{~mm}$ (중앙값 $1162.2 \mathrm{~mm}$ )이고, 차단량은 $109.1 \sim 196.2 \mathrm{~mm}$ 로 평균 150.6 $\mathrm{mm}$ (중앙값 $152.0 \mathrm{~mm}$ )으로 분석되었다. 그리고, 증발산량 은 537.7 644.5 mm로 평균 $591.6 \mathrm{~mm}$ (중앙값 $591.0 \mathrm{~mm}$ ) 이고, 지표유출량은 83.9 501.9 mm로 평균 $272.9 \mathrm{~mm}$ (중 앙값 $238.5 \mathrm{~mm}$ )로 분석되었다. 연간 강수량 대비 차단량, 지표유출량, 증발산량은 각각 10.1 16.4\%(평균 $12.7 \%$ ), $10.5 \sim 28.7 \%$ (평균 $21.7 \%$ ), 32.5 72.2\%(평균 $51.1 \%$ )의 분 포를 나타내었다.

강수량으로부터 이들 차단량, 증발산량, 지표유출량을 제외한 나머지는 지하수 함양량과 토양수분함량을 변화 시키는데, 연 단위의 장기간 동안 토양수분변화는 거의 일정하게 나타나므로 분석결과에서는 제외하였다. VELAS 모형에서 산정된 연간 지하수 함양량은 28.8 492.9 mm 로 평균 $196.9 \mathrm{~mm}$ (중앙값 $162.9 \mathrm{~mm}$ )로 분석되었다. 연 강수량 대비 지하수 함양률은 최소 $3.6 \%$ 에서 최대 $28.2 \%$ 로 변동폭이 매우 크고, 평균 함양률은 $14.9 \%$ (중앙값 $14.8 \%$ )였다.

연도별 지하수함양량은 2015년에 $28.8 \mathrm{~mm}$ 로 가장 적 은 함양량을 나타내었으며, 이 양은 전체 지하수 함양량

Table 2. Annual water budget analysis results in the past (2001 2018)

\begin{tabular}{|c|c|c|c|c|c|c|}
\hline Year & $\begin{array}{l}\text { Precipitation } \\
(\mathrm{mm} / \mathrm{yr})\end{array}$ & $\begin{array}{l}\text { Interception } \\
(\mathrm{mm} / \mathrm{yr})\end{array}$ & $\begin{array}{c}\text { Runoff } \\
(\mathrm{mm} / \mathrm{yr})\end{array}$ & $\begin{array}{l}\text { Evapotranspiration } \\
(\mathrm{mm} / \mathrm{yr})\end{array}$ & $\begin{array}{c}\text { Groundwater recharge } \\
(\mathrm{mm} / \mathrm{yr})\end{array}$ & $\begin{array}{c}\text { Recharge rate } \\
(\%)\end{array}$ \\
\hline 2001 & 1037.6 & 118.6 & 234.7 & 584.0 & 103.7 & 10.0 \\
\hline 2002 & 1071.5 & 130.9 & 217.8 & 616.3 & 78.0 & 7.3 \\
\hline 2003 & 1459.8 & 173.0 & 364.6 & 644.5 & 281.0 & 19.3 \\
\hline 2004 & 1213.2 & 153.4 & 242.3 & 631.5 & 181.0 & 14.9 \\
\hline 2005 & 1307.2 & 131.7 & 356.6 & 598.9 & 226.0 & 17.3 \\
\hline 2006 & 890.7 & 113.1 & 197.9 & 574.2 & 103.7 & 11.6 \\
\hline 2007 & 1405.3 & 173.8 & 317.4 & 566.8 & 266.5 & 19.0 \\
\hline 2008 & 1069.0 & 172.4 & 167.1 & 590.9 & 155.9 & 14.6 \\
\hline 2009 & 1262.1 & 174.3 & 270.7 & 622.3 & 169.9 & 13.5 \\
\hline 2010 & 1654.6 & 196.2 & 459.2 & 604.2 & 431.3 & 26.1 \\
\hline 2011 & 1750.8 & 186.1 & 501.9 & 569.8 & 492.9 & 28.2 \\
\hline 2012 & 1496.4 & 156.9 & 414.0 & 543.1 & 347.4 & 23.2 \\
\hline 2013 & 1111.3 & 144.1 & 230.0 & 616.7 & 133.8 & 12.0 \\
\hline 2014 & 1054.2 & 157.1 & 177.9 & 583.6 & 133.0 & 12.6 \\
\hline 2015 & 799.1 & 130.7 & 83.9 & 577.3 & 28.8 & 3.6 \\
\hline 2016 & 869.8 & 109.1 & 147.9 & 591.1 & 33.4 & 3.8 \\
\hline 2017 & 1014.4 & 150.6 & 180.1 & 537.7 & 151.7 & 15.0 \\
\hline 2018 & 1325.9 & 139.3 & 348.3 & 594.8 & 225.3 & 17.0 \\
\hline Minimum & 799.1 & 109.1 & 83.9 & 537.7 & 28.8 & 3.6 \\
\hline Maximum & 1750.8 & 196.2 & 501.9 & 644.5 & 492.9 & 28.2 \\
\hline Average & 1210.7 & 150.6 & 272.9 & 591.6 & 196.9 & 14.9 \\
\hline Median & 1162.2 & 152.0 & 238.5 & 591.0 & 162.9 & 14.8 \\
\hline
\end{tabular}




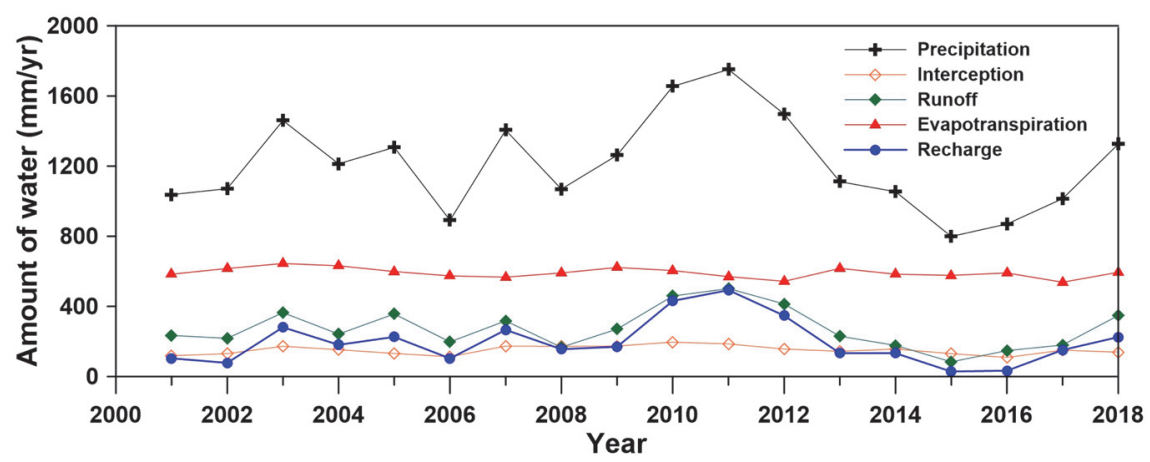

Fig. 4. Annual variation of each water budget element in the past (2001 2018).

평균인 $196.9 \mathrm{~mm}$ 에 비하여 $14.6 \%$ 에 지나지 않는 양이 다. 또한, 2015년과 2016년에 연속적으로 지하수 함양량 이 각각 $28.8 \mathrm{~mm}, 33.4 \mathrm{~mm}$ 로 가장 적은 지하수 함양량 을 나타내었다. 지하수 함양량이 가장 많았던 해는 2011 년도이고 $492.9 \mathrm{~mm}$ 가 함양된 것으로 분석되었으며, 이 때의 연간 지하수 함양률은 $28.2 \%$ 이었다.

Figure 5는 강수량과 지하수 함양량과의 관계를 나타낸 그림이다. 일단위에서 월단위, 연단위로 가면서 강수량과 상관성은 더 높아 지고 있으며, 이러한 추세는 강수량, 함양량의 i번째와 i- 1 번째의 값들의 차이와 비교하여 보 면 이러한 경향성이 더 뚜렷하게 나타나는 것을 알 수
있다. 일 강수량과 일 지하수 함양량 사이의 결정계수, $\mathrm{R}^{2}$ 은 0.21 , 월 강수량과 월 지하수 함양량과의 결정계수, $\mathrm{R}^{2}$ 은 0.74 , 연 강수량과 연 지하수 함양량과의 결정계수, $\mathrm{R}^{2}$ 은 0.93 으로 분석되었다. 강수량과 지하수 함양량의 $\mathrm{i}$ 번째와 i- 1 번째의 값들에 대한 $\mathrm{R}^{2}$ 는 일, 월, 연 단위에서 각각 $0.21,0.60,0.87$ 로 연단위로 갈수록 양의 상관성이 뚜렷하게 나타나고 있다. 지하수 함양량은 물론 강수량 도 중요하지만 토양수분함량, 강수지속시간, 강수강도과 도 밀접하게 연관되어 있다. 따라서, 월, 연단위에서 보 다 일단위에서의 강수량과 지하수 함양량과의 결정계수 가 낮은 것으로 판단된다. 즉, 일단위에서 월단위, 연단
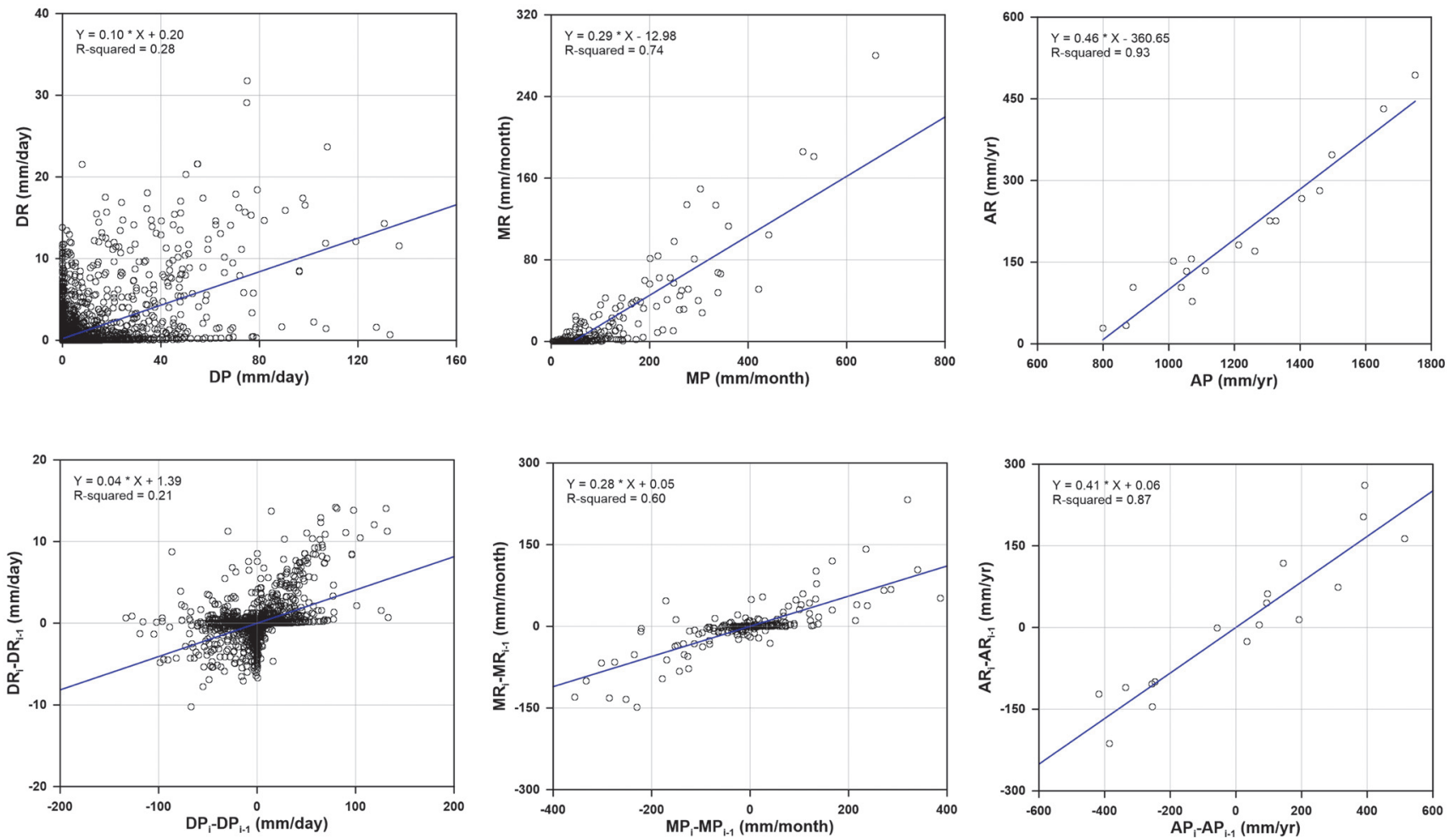

Fig. 5. Relationships between annual precipitation and recharge, recharge rate in the past (2001 2018). 
위로 갈수록 토양수분함량, 강수지속시간, 강수강도와 같 은 민감도가 둔화되고, 평균화되기 때문에, 함양량과 강 수량과의 관계에서 결정계수가 높아지는 것으로 보인다.

Figure 6은 월별로 수문요소별 변동을 박스도로 나타낸 것이다. 2001년부터 2018년까지 18년 동안 강수량은 월 평균으로 볼 때, 7월에 $291.5 \mathrm{~mm}$ 로 가장 높았지만, 변동 폭은 8월에 26.1 533.6 mm로 가장 크게 나타났다. 강수 에 대한 차단량도 역시 강수량과 같이 평균은 7월이 가 장 크지만, 변동폭이 가장 큰 달은 8월로 $6.6 ~ 56.1 \mathrm{~mm}$ 의 범위에서 변동하였으며, 강수량 대비 평균 $12.4 \%$ 를 나타 내었다. 지표유출량은 7월, 8월, 9월에 그 변동폭이 가장 큰데, 7월에 그 변동폭이 다소 다른 달보다 크게 나타났
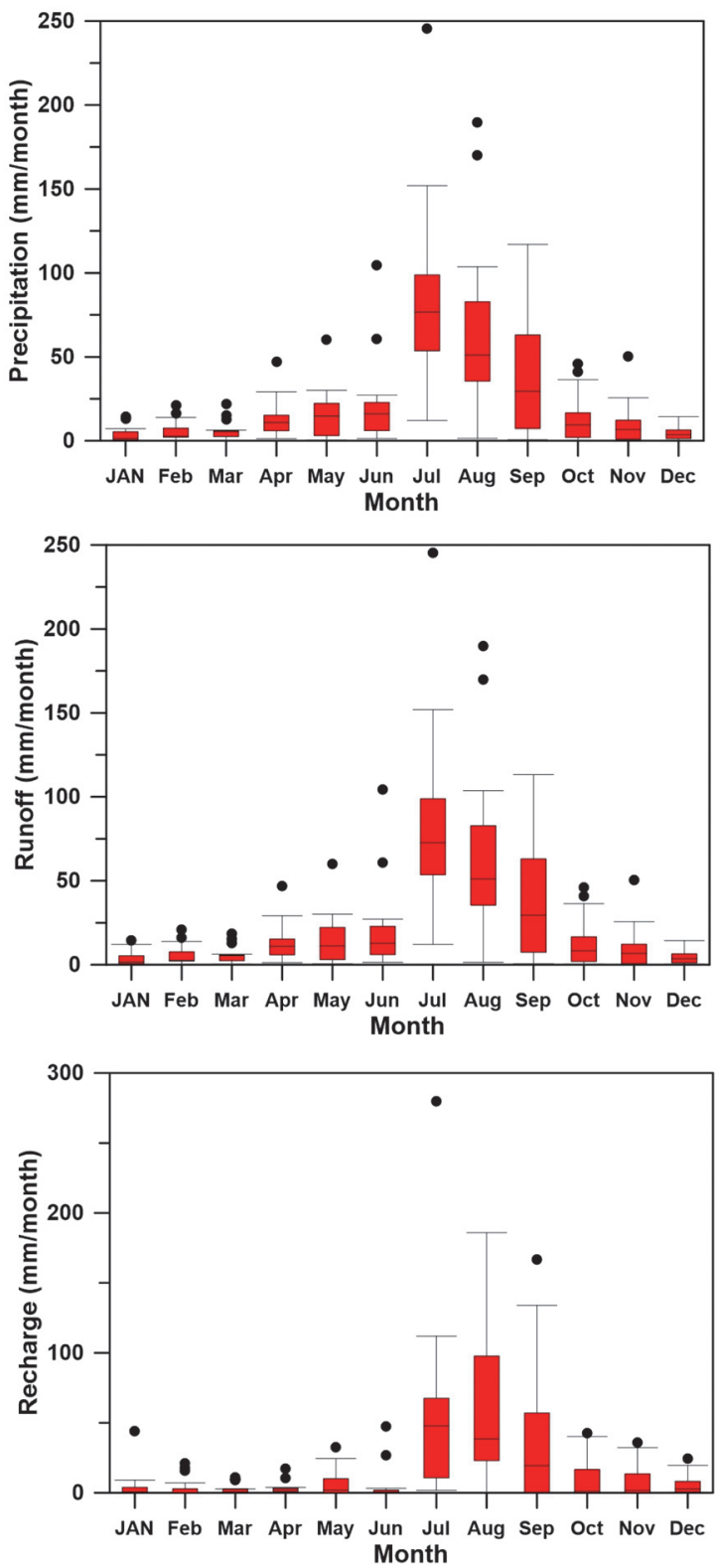

다. 지표유출량이 강수량 대비 차지하는 비율은 평균 $22.5 \%$ 를 차지하였다.

증발산량은 강수보다는 기온에 따른 계절적 변동과 관 련되어 나타나고 있으며, 5월의 증발산량이 $26.2 \sim 89.6 \mathrm{~mm}$ (평균 73.2 mm)로서 6월과 7월의 증발산량인 26.1 84.2 mm (평균 $69.1 \mathrm{~mm}$ ), $21.6 \mathrm{~mm} 84.6 \mathrm{~mm}$ (평균 $72.7 \mathrm{~mm}$ )보 다 다소 높은 값을 나타내었다. 이와 같은 분포가 나타 나는 이유는 6 월부터 8 월에 이르는 시기는 기온은 높지 만, 강수도 많이 발생하기 때문으로 판단된다.

월별 강수량 대비 차단량, 지표유출량, 증발산량의 비 율은 각각 5.3 30.2\%(평균 14.3\%), 1.3 45.0\%(평균 15.1\%), $10.7 \sim 545.5 \%$ (평균 90.0\%)로 나타났다. 월별로 강수량이
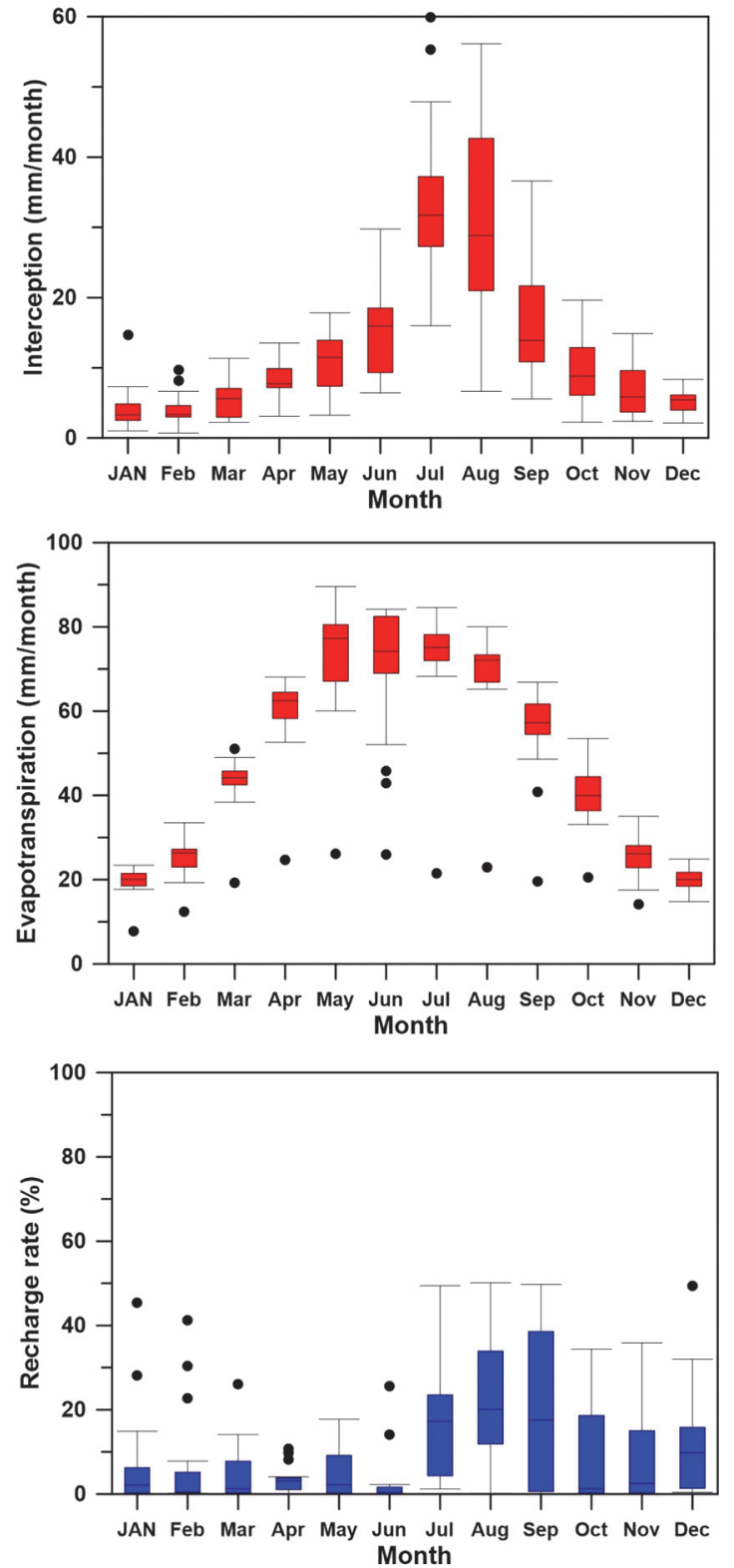

Fig. 6. Monthly variation for each water budget element in the past (2001 2018). 
적은 시기에는 증발산량이 강수량을 초과하는 것으로 나타 나고 있으므로, 작물이 성장하는 시기라고 하면, 관개용수 의 공급문제가 발생하였을 개연성이 크다. 월별 지하수 함양량은 7월과 8월에 각각 1.8 280.0 mm(평균 $58.8 \mathrm{~mm}$ ), 0 185.9 mm (평균 $65.6 \mathrm{~mm}$ )로 가장 많았지만, 그 변동 량도 이 시기에 가장 컸다.

\section{2. 타 모델에 의한 물수지 비교}

물수지 분석결과에 대하여 검증은 일반적으로 하천의 유출량 자료를 맞추어보는 것으로 이루어지지만(Park et al., 2013), 연구지역에서 실제 관측된 지표유출량 자료는 없기 때문에, 이를 통한 검증은 불가능한 상황이다. 따라 서, 그에 대한 대안으로 기존에 이루어진 지하수 함양량 산정에 대한 연구 및 조사결과를 비교하였다.

기존에 연구지역에서 이루어진 물수지 분석은 WETSPASS 모델을 통하여 이루어졌으며, 이에 근거한 연간 지하수 함양량도 산정된 바 있다(KIGAM et al., 2018). WETSPASS 는 준 정상류 상태에서 토양과 식물, 대기사이의 물과 에 너지 교환(Water and Energy Transfer between Soil, Plants and Atmosphere under quasi-Steady State)을 모사할 수 있는 모델이다(Batelaan and de Smedt, 2001). WETSPASS 는 식생을 고려하여 토양층내 물수지를 계산하는 측면에 서 VELAS 모형과 비슷하지만, 차단량을 증발산량에 포 함하여 계산하고, 지표유출량 계산을 NRCS-CN방법이 아닌 합리식(rational formula)을 이용했다는 점에서 큰 차 이가 난다. 무엇보다도 WETSPASS는 물수지를 평가하는 시간단위가 반기 또는 연이기 때문에 보다 상세한 시간 단위에서는 적용할 수 없다는 단점을 가진다. 여기에서 는 WETSPASS의 입력 자료로 2007년부터 2016년까지 10 년간 서산 기상관측소의 평균온도, 최고온도, 최저온도, 일강수량, 평균풍속 자료를 적용하였으며, 그 결과 지하 수함양량은 연평균 강수량 대비 $18.6 \%$ 로 산정되었다 (KIGAM et al., 2018). 이 기간 동안 VELAS에 의한 연 평균 물수지는 강수량, 차단량, 지표유출량, 증발산량이 각각 3,529 천 $\mathrm{m}^{3} / \mathrm{yr}, 453$ 천 $\mathrm{m}^{3} / \mathrm{yr}$ (강수량 대비 $12.8 \%$ ), 784 천 $\mathrm{m}^{3} / \mathrm{yr}$ (강수량 대비 $22.2 \%$ ), 1,661 천 $\mathrm{m}^{3} / \mathrm{yr}$ (강수량 대비 $47.1 \%$ )이었으며, 지하수함양량은 $620 \mathrm{k}^{2} \mathrm{~m}^{3} / \mathrm{yr}$ 으로 강수량 대비 $17.6 \%$ 였다.

WETSPASS에 의해 산정된 연간 지하수 함양량과 VELAS 모형에 의해 일단위로 산정된 지하수 함양량을 연간으로 환산한 양과 비교할 때, 각 모델이 이용하는 수식과 방 법이 다름에도 서로 비슷한 지하수 함양량을 나타낸 것 을 알 수 있다. VELAS 모형도 하나의 셀에 대하여 식생, 토양, 수류, 불투수면적과 같이 서브셀(Sub-cell)로 나누 어 물수지를 계산하는 WETSPASS 모델의 방식을 차용
하고 있다. 다만, 물수지를 이루는 구성요소인 차단량, 증 발산량, 지표유출량을 계산하는 방식들이 서로 다르다. 연간 물수지 모델로 검증된 모델인 WETSPASS에 의한 결과가 VELAS 모델에 의한 결과와 비교적 일치하는 결 과는 이렇게 산정된 지하수 함양량이 어느 정도 타당하 다는 것을 시사해 주고 있는 것으로 생각된다.

또한, 2004-2005년 시행된 홍성지역 지하수 기초조사 에서는 연구지역이 포함된 유역에서 기저유출량에 의한 지하수 함양량이 강수량 대비 $12.5 \%$ 로 산정되었다. 그리 고, 지하수 수위강하곡선 분석 방법에 의해서는 관측정 별로 매우 큰 편차를 보여, 5.1 14.6\%의 지하수 함양률 분포를 보였다(MCT et al., 2005). 금번 VELAS 모형에 서는 연구지역의 2004년과 2005년의 연간 지하수 함양 률이 각각 $14.9 \%, 17.3 \%$ 로 산정되었다. 각각의 지하수 함양률 산정방법에는 한계점이 존재하고 있기 때문에, 어 떤 결과가 가장 정확하다고 단정할 수는 없지만, 본 연 구에서 VELAS 모형은 타 방법에 의한 지하수 함양량 평 가 결과와 어느 정도 합치되는 결과를 보여주었다.

\section{3. 미래 기후변화 RCP 8.5시나리오에 의한 물수지 (2019년 2100년)}

Table 3과 Figure 7은 미래 기후변화 RCP 8.5시나리오 에 의한 일단위 물수지 분석 결과(2019년 2100년)에 대 하여 연도별로 수문요소를 분석한 결과를 나타낸 것이다. 전체 기간 동안 강수량은 최소 $572.8 \mathrm{~mm}$, 최대 $1996.5 \mathrm{~mm}$, 평균 $1078.4 \mathrm{~mm}$ (중앙값 $1022.0 \mathrm{~mm}$ )로 나타났다. 차단량 은 최소 $81.5 \mathrm{~mm}$, 최대 $168.4 \mathrm{~mm}$, 평균 $123.7 \mathrm{~mm}$ (평균 강수량의 $11.5 \%$ ), 중앙값 $121.0 \mathrm{~mm}$ 이다. 지표유출량은 최소 $78.6 \mathrm{~mm}$, 최대 $877.4 \mathrm{~mm}$, 평균 $261.4 \mathrm{~mm}$ (평균 강 수량의 $24.4 \%$ ), 중앙값 $226.8 \mathrm{~mm}$ 이다. 증발산량은 최소 $387.0 \mathrm{~mm}$, 최대 $632.6 \mathrm{~mm}$, 평균 $521.6 \mathrm{~mm}$ (평균 강수량 의 $48.4 \%$ ), 중앙값 $524.6 \mathrm{~mm}$ 이다. 지하수함양량은 최소 $26.7 \mathrm{~mm}$, 최대 $432.5 \mathrm{~mm}$, 평균 $174.6 \mathrm{~mm}$ (평균 강수량 의 $16.2 \%$ ), 중앙값 $167.1 \mathrm{~mm}$ 로서 과거보다 다소 증가하 였다. 연간 지하수 함양률은 최소 $2.8 \%$, 최대 $45.1 \%$, 평 균 $18.2 \%$ 로 분석되었다.

또한, Table 3은 2019년부터 2100년까지 기후변화 시 나리오에 의한 연도별 분포를 약 20 년 단위별, 4 개 시기 로 나누어 그 분포를 나타내었다. 강수량은 3 번째 시기 인 2016년부터 2080년까지 기간이 가장 많았고, 그에 따 라 차단량과 지표유출량도 이 시기에 가장 많았다. 증발 산량은 시기별로 첫번째 시기부터 네번째 시기로 갈수록 증가하는 경향을 보여주었으며, 지하수함양량과 함양률 은 세번째 시기에서 다른 시기보다도 다소 높게 나타났 다. 수문요소별 상호 관계를 살펴보면 차단량, 지표유출 
Table 3. Basic statistics of the annual water budget analysis results during each period of the future (2019-2100)

\begin{tabular}{|c|c|c|c|c|c|c|}
\hline \multirow{2}{*}{\multicolumn{2}{|c|}{ Hydrologic elememt }} & \multicolumn{5}{|c|}{ Period } \\
\hline & & $\begin{array}{c}\text { Total } \\
(2019-2100)\end{array}$ & $\begin{array}{c}1 \mathrm{st} \\
(2019-2040)\end{array}$ & $\begin{array}{c}\text { 2nd } \\
(2041-2060)\end{array}$ & $\begin{array}{c}\text { 3rd } \\
(2061-2080)\end{array}$ & $\begin{array}{c}\text { 4th } \\
(2081-2100)\end{array}$ \\
\hline \multirow{4}{*}{$\begin{array}{l}\text { Precipitation } \\
\quad(\mathrm{mm} / \mathrm{yr})\end{array}$} & Minimum & 572.8 & 630.1 & 722.3 & 773.1 & 572.8 \\
\hline & Maximum & 1996.5 & 1544.1 & 1577.2 & 1996.5 & 1646.5 \\
\hline & Average & 1078.4 & 1048.2 & 1024.1 & 1159.2 & 1085.1 \\
\hline & Median & 1022.0 & 1001.2 & 972.2 & 1108.1 & 1113.2 \\
\hline \multirow{4}{*}{$\begin{array}{l}\text { Interception } \\
(\mathrm{mm} / \mathrm{yr})\end{array}$} & Minimum & 81.5 & 85.7 & 91.3 & 101.7 & 81.5 \\
\hline & Maximum & 168.4 & 166.3 & 162.1 & 168.4 & 158.4 \\
\hline & Average & 123.7 & 125.1 & 117.7 & 127.2 & 124.7 \\
\hline & Median & 121.0 & 125.1 & 118.3 & 128.1 & 123.0 \\
\hline \multirow{4}{*}{$\begin{array}{l}\text { Runoff } \\
(\mathrm{mm} / \mathrm{yr})\end{array}$} & Minimum & 78.6 & 110.2 & 78.6 & 137.8 & 88.0 \\
\hline & Maximum & 877.4 & 490.1 & 500.6 & 877.4 & 577.9 \\
\hline & Average & 264.4 & 251.5 & 237.8 & 295.8 & 261.7 \\
\hline & Median & 226.8 & 209.7 & 204.9 & 256.0 & 253.3 \\
\hline \multirow{4}{*}{$\begin{array}{l}\text { Evapotranspiration } \\
\qquad(\mathrm{mm} / \mathrm{yr})\end{array}$} & Minimum & 387.0 & 387.0 & 459.5 & 432.0 & 418.6 \\
\hline & Maximum & 632.6 & 564.5 & 568.9 & 605.7 & 632.6 \\
\hline & Average & 521.6 & 493.7 & 516.5 & 539.1 & 540.0 \\
\hline & Median & 524.6 & 503.4 & 510.4 & 544.9 & 545.3 \\
\hline \multirow{4}{*}{$\begin{array}{l}\text { Recharge } \\
(\mathrm{mm} / \mathrm{yr})\end{array}$} & Minimum & 26.7 & 47.4 & 26.7 & 45.1 & 28.6 \\
\hline & Maximum & 432.5 & 410.8 & 432.5 & 384.5 & 354.3 \\
\hline & Average & 174.6 & 180.4 & 157.0 & 194.5 & 166.0 \\
\hline & Median & 167.1 & 153.0 & 135.2 & 182.2 & 177.2 \\
\hline \multirow{4}{*}{$\begin{array}{c}\text { Recharge rate } \\
(\%)\end{array}$} & Minimum & 2.8 & 4.9 & 4.9 & 4.7 & 3.0 \\
\hline & Maximum & 45.1 & 42.8 & 42.8 & 40.1 & 37.0 \\
\hline & Average & 18.2 & 18.8 & 18.8 & 20.3 & 17.3 \\
\hline & Median & 17.4 & 16.0 & 14.1 & 19.0 & 18.5 \\
\hline
\end{tabular}

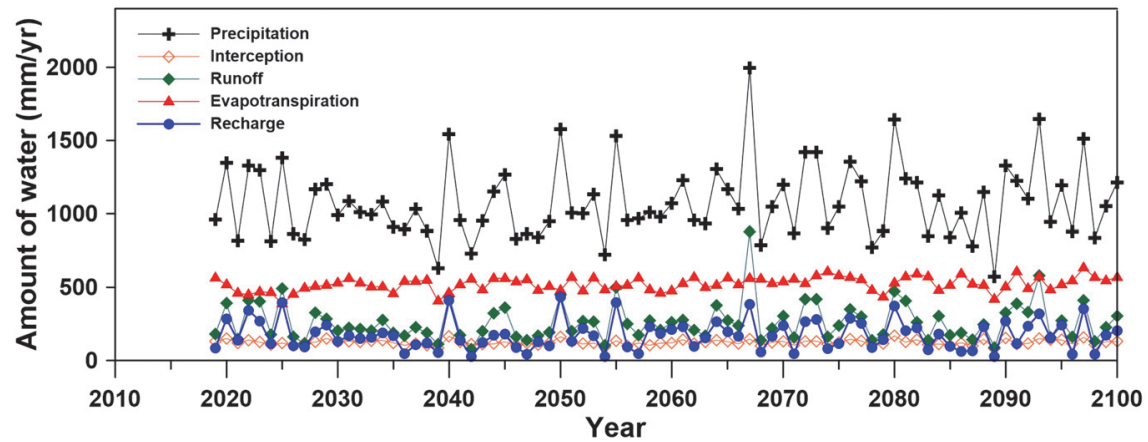

Fig. 7. Annual variation for each water budget element for the future (2019 2100).

량, 지하수 함양량과 함양률은 강수량과 연계되어 변동 하는 양상이 잘 나타나지만, 증발산량은 강수량보다는 다 른 요인, 즉 기후변화에 의한 기온상승에 대한 영향이 크 게 반영된 것으로 보인다.
Figure 8은 연도별 각 수문요소에 대한 변동성을 나타 낸 그래프이다. 2019년부터 2100년까지 연간 강수량 변 화 추이는 약간 증가하는 경향을 보이고, 이와 함께 증 발산량, 지표유출량도 증가 경향이 있으며, 차단량과 지 

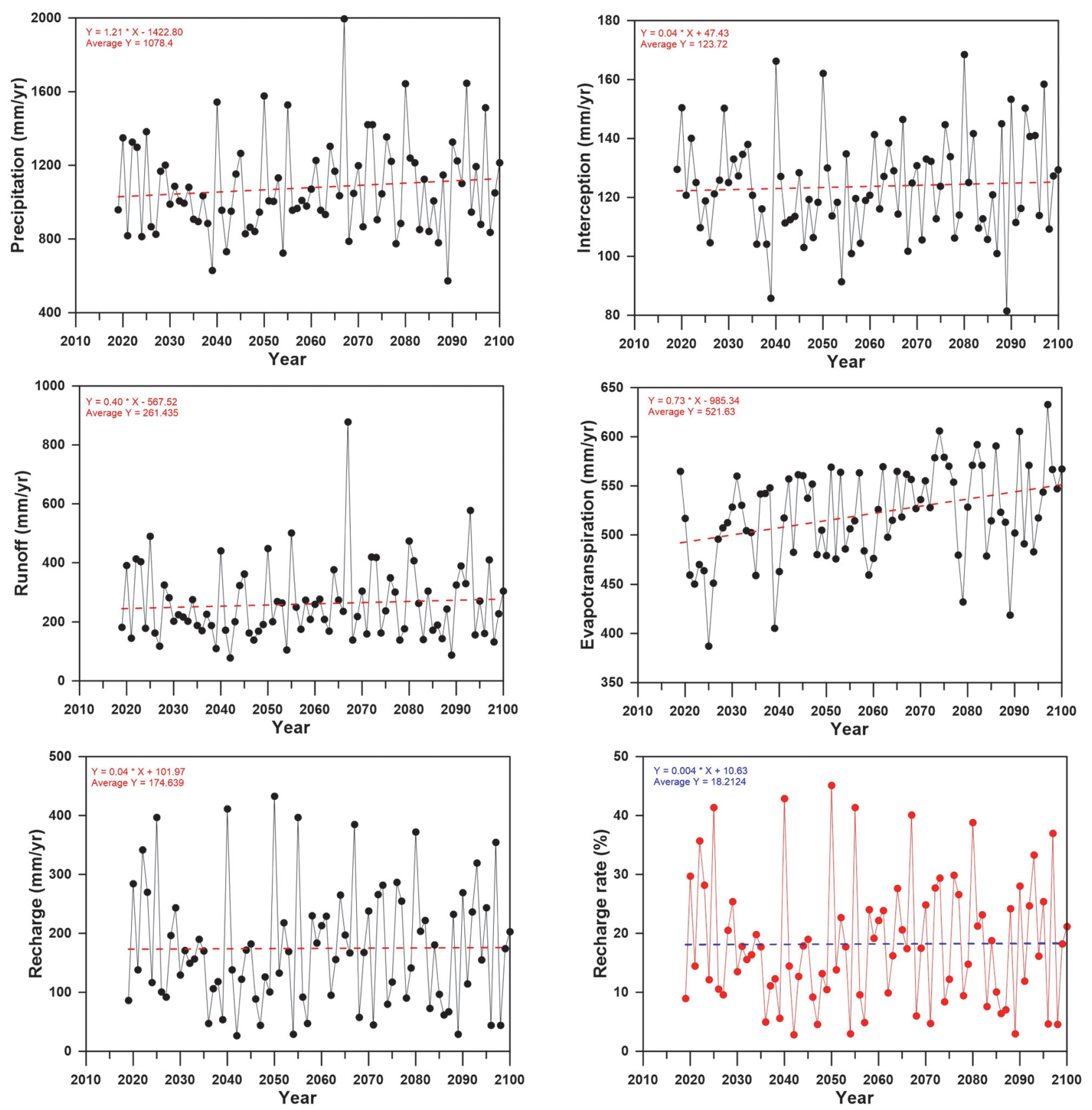

Fig. 8. Monthly variation for each water budget element for the future (2019 2100).

하수 함양량은 증가하고는 있지만, 증가세가 다른 요소 에 비하여 뚜렷하지는 않다. 지하수 함양률은 거의 일정 하다고 봐도 무방하다. 그러나, 연간 수문요소별 변동은 최소값과 최대값의 차이가 2배 이상으로 나타나고 있고, 특히 지표유출량과 지하수 함양량은 그 차이가 10 배 이 상으로 매우 크게 나타났다.

Figure 9는 미래 기후변화 RCP 8.5시나리오에 의한 일 단위 물수지 분석결과(2019년 2100년)에 대하여 월단위 로 환산된 수문요소 변동을 박스도로 나타낸 것이다. 강
수량은 현재와 비슷한 양상으로 6 8월에 집중되는 양상 이고, 이때에는 그 변동폭도 크게 나타났다. 강수량에 대 하여 차단량과 지표유출량, 지하수 함양량은 수량은 다 르지만, 분포양상은 비슷했다. 마찬가지로 지하수 함양률 도 함양량과 비슷한 양상을 보였다. 다만, 증발산량은 다 른 수문요소들과는 달리 4월부터 8월까지 기간에 변동폭 이 가장 적고 나머지 기간에는 변동폭이 큰 양상을 나타 내었다. 

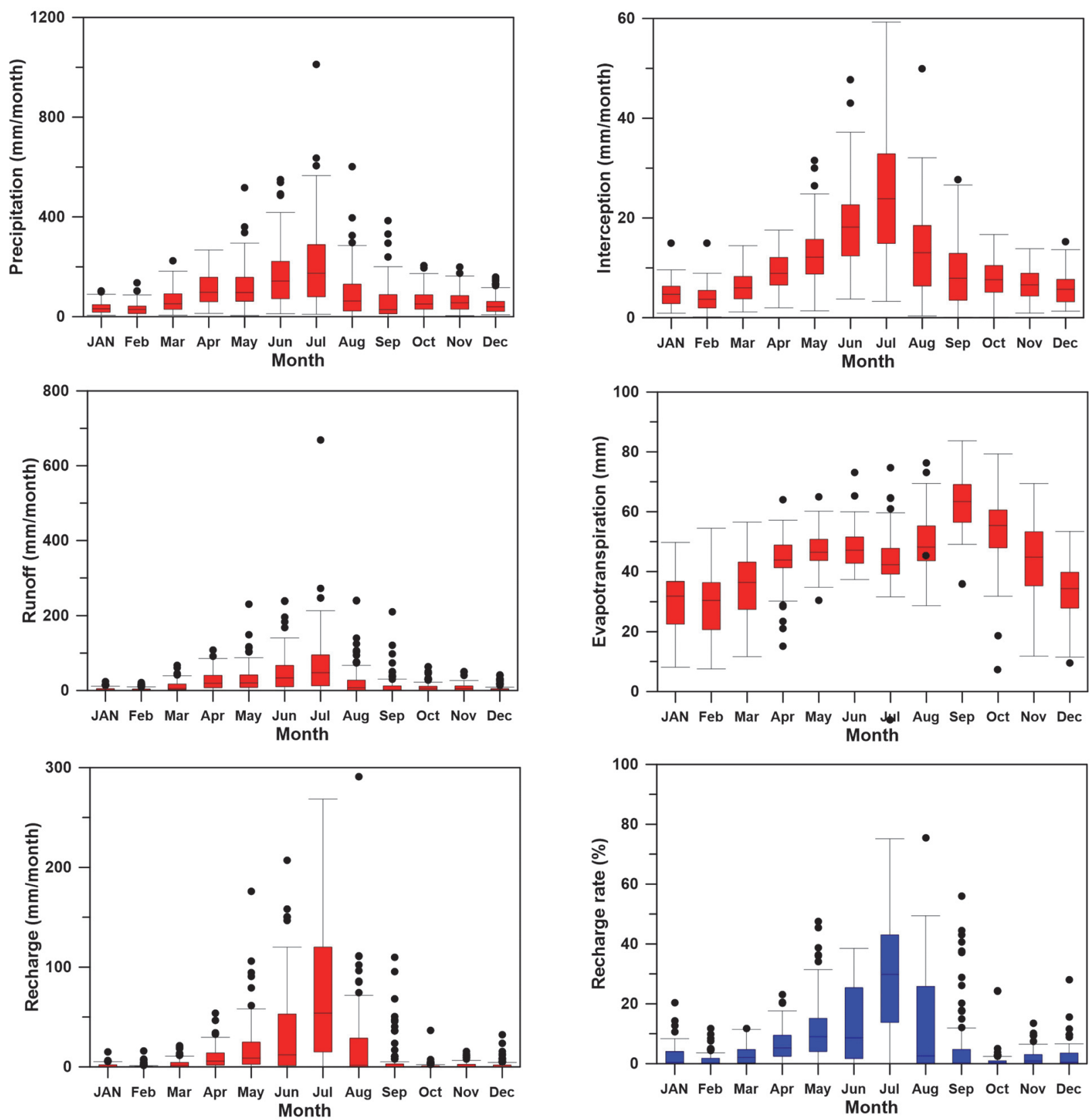

Fig. 9. Monthly variation for each water budget element in the past (2019 2100).

\section{4. 결 론}

본 연구에서는 분포형 수문모형중의 하나인 VELAS 모 형을 이용하여 격자 단위로 일단위의 물수지 분석과 이 를 통한 지하수 함양량을 평가함으로써, 연간이 아닌, 월 별 또는 시기별로 지하수 함양량을 평가할 수 있었다. 연 구지역의 과거 2001년부터 2018년까지 18년 동안 연도 별 물수지 분석 결과, 연간 강수량은 연간 강수량은 $799.1 \sim 1750.8 \mathrm{~mm}$ 로 평균 $1210.7 \mathrm{~mm}$ 이고, 연간 강수량 대비 차단량, 지표유출량, 증발산량은 각각 $10.1 ~ 16.4 \%$ (
평균 $12.7 \%$ ), 10.5 28.7\%(평균 21.7\%), 32.5 72.2\%(평균 $51.1 \%$ )의 분포를 나타내었다. 연간 지하수 함양량은 28.8 492.9 mm로 평균 $196.9 \mathrm{~mm}$ 로 분석되었으며, 연 강 수량 대비 지하수 함양률은 최소 $3.6 \%$ 에서 최대 $28.2 \%$ 로 변동폭이 매우 크고, 평균 함양률은 $14.9 \%$ 였다.

미래 기후변화 RCP 8.5시나리오에 의한 2019년부터 2100 년까지의 일단위 물수지 분석결과를 연도별로 환산 하면 강수량은 $572.8 ~ 1996.5 \mathrm{~mm}$ (평균 $1078.4 \mathrm{~mm}$ )이고, 차단량은 $81.5 \sim 168.4 \mathrm{~mm}$, 평균 $123.7 \mathrm{~mm}$ (평균 강수량의 $11.5 \%$ ), 지표유출량은 78.6 877.4 mm, 평균 $261.4 \mathrm{~mm}$ (평 
균 강수량의 $24.4 \%$ ), 증발산량은 $387.0 \sim 632.6 \mathrm{~mm}$, 평균 $521.6 \mathrm{~mm}$ (평균 강수량의 $48.4 \%$ ), 지하수함양량은 26.7 $432.5 \mathrm{~mm}$, 평균 $174.6 \mathrm{~mm}$ (평균 강수량의 $16.2 \%$ )로서 과 거보다 다소 증가하였다. 연간 지하수 함양률은 최소 $2.8 \%$, 최대 $45.1 \%$, 평균 $18.2 \%$ 로 분석되었다.

VELAS 모형은 격자 상에서 토양수분 평형식에 입각 하여 일단위로 강수량, 차단량, 증발산량, 지하수 함양량 을 제시할 수 있고, 토지피복과 식생의 연간 성장과 쇠 퇴과정을 고려할 수 있는 장점이 있으므로, 기상요소 뿐 만이 아닌 지표환경변화를 고려하여 수문 변화를 모의할 수 있다는 장점이 있다. 따라서 과거와 미래의 지하수 함 양량에 대한 변화를 평가하고, 이에 따른 지하수 흐름 변 화 모색이 가능하다. 뿐만 아니라, 연단위에서 월단위, 또 는 일단위로 보다 상세한 시간간격에서 물수지 분석결과 를 나타내 보여주기 때문에 지하수 관리에 매우 유용하 게 활용될 수 있을 것이다.

\section{사 사}

본 연구는 환경부의 수요대응형 물공급 서비스사업에 서 지원받았습니다.

\section{References}

Abbot, M.B., Bathurst, J.C., Cunge, P.E., Connell, O. and Rasmussen, J. (1986) An introduction to the European hydrological systemSysteme Hydrologique Europeen, SHE, 1: Histroy and Philosophy of a physically-based, distributed modeling system. Journal of Hydrology, v.87, p.45-59. doi: 10.1016/0022-1694(86) 90114-9

Allen, R.G., Pereira, L.S., Raes, D. and Smith, M. (1998) Crop Evapotranspiration: Guidelines for Computing Crop Water Requirements, FAO Irrigation and Drainage Paper No. 56, Rome.

Arnold, J.G., Srinivasan, R., Muttiah,R.S. and Allen, P.M. (1999) Continentalscale simulation of the hydrologic balance. Journal of the American Water Resources Association, JAWRA v.35(5), p.1037-1051. doi: 10.1111/j.1752-1688.1999.tb04192.x

Bae, S.-K. and Kim, Y.-H. (2006) Estimation of groundwater recharge rate using the NRCS-CN and baseflow separation methods. Journal of Environmental Science International, v.15(3), p.253260. doi: 10.5322/JES.2006.15.3.253

Batelaan, O. and de Smedt (2001) WetSpass: a flexible, GIS based, distributed recharge methodology for regional groundwater modelling, Impact of Human Activity on Groundwater Dynamics (Proceedings of a symposium held during the Sixth IAHS Scientific Assembly at Maastricht, The Netherlands, July 2001). IAHS Publ. no. 269, p.11-17.

Choi, B.-S. and Ahn, J.-G. (1998) A study on the estimation of regional groundwater recharge ratio. Journal of the Korean Society of Groundwater Environment, v.5(2), p.57-65.
DHI (Danish Hydraulic Institute) (1999) MIKE SHE Water Movement: User manual, Denmark: Hørsholm, Danish Hydraulic Institute.

Harbaugh, A.W., Banta, E.R., Hill, M.C. and McDonald, M.G. (2000) MODFLOW-2000, the US Geological Survey Modular Ground-Water Model - User Guide to Modularization Concepts and the Ground-Water Flow Process. Open-File Report 00-92, US Geological Survey. doi: 10.3133/ofr200092

Healy, R.W. and Cook, P.G. (2002) Using groundwater levels to estimate recharge. Hydrogeology Journal, v.10, p.91-109. doi: 10.1007/s10040-001-0178-0

Jang, C.H., Kim, H.J., Kim, Y.M. and Nam, M.A. (2013) Assessing the effect of water and heat cycle of green roof system using distributed hydrological model in urban area. Journal of the Korea Institute of Ecological Architecture and Environment, v.13(4), p.33-41. doi: 10.12813/kieae.2013.13.4.033

Jarvis, A., Reuter, H.I., Nelson, A. and Guevara, E. (2008) Holefilled seamless SRTM data V4, International Centre for Tropical Agriculture (CIAT), http://srtm.csi.cgiar.org (accessed 19.01.09).

KICT(Korea Institute of Construction and Transportation) (2007) Development of analyzing system for surface water hydrological components, $21^{\text {st }}$ Century Frontier R\&D program -Sustainable Water Resources Research Program, 384p.

KIGAM(Korea Institute of Geoscience and Mineral Resources) (2012) Development of integrated core technologies in aquifer recharge system for groundwater sustainability, GP2012-0132012(1), 267p.

KIGAM(Korea Institute of Geoscience and Mineral Resources), KRC(Korea Rural Community Corporation), and GeoGreen21 (2018) Annual performance and plan for Well network system technology development against Drought, Environmental Technology Development Project, 170p.

Kim, C.G, Kim, H., Jang, C.H. and Im, S.J. (2007) Groundwater recharge estimation of the Gyeongan-cheon watershed with MIKE SHE modeling system, J. Korea Water Resour. Assoc., v.40(6), p.459-468. doi: 10.3741/JKWRA.2007.40.6.459

Kim, G.-B., Yi, M.-J., Kim, J.-W., Lee, J.-Y. and Lee, K.-K. (2004) Evaluation of estimating groundwater recharge using waterlevel data obtained from the national groundwater monitoring stations. The Journal of Engineering Geology, v.14(3), p.313-323.

Kim, M., Jeong, G., Lee, J.E. and Kim, M. (2020) Estimating exploitable groundwater as a function of precipitation using a distributed hydrologic model and frequency analysis. The Journal of Engineering Geology, v.30(3), p.253-268. doi: 10.9720/kseg.2020.3.253

Kim, N.W., Lee, J., Chung, I.M. and Kim, D.P. (2008) Hydrologic component analysis of the Seolma-Cheon watershed by using SWAT-K model, Journal of Environmental Science International, v.17(12), p.1363-1372. doi: 10.5322/JES.2008.17.12.1363

Kim, N.W., Shin, A.H. and Kim, C.G. (2009) Comparison of SWAT$\mathrm{K}$ and HSPF for Hydrological Components Modeling in the Chungju Dam Watershed, Journal of Environmental Science International, v.18(6), p.609-619. doi: 10.5322/JES. 2009.18.6.609

Kim, S.W., Park, S.-I., Ko, K., Lee, H.-J., Kihm, Y.H. and Lee, S.R. (2014) 1:100,000 Tectonostratigraphic map of the Hongseong area, map 1: solid geology interpretation; Korea Institute of 
Geoscience and Mineral Resources.

KMA(Korea Meteorological Agency) (2018) Analysis of Climate Change Forecasts on the Korean Peninsula, 172p.

Koo, M.-H. and Lee, D.-H. (2002) A numerical analysis of the water level fluctuation method for quantifying groundwater recharge. Journal of the Geological Society of Korea, v.38(3), p.407-420.

KSIS(Korea Soil Information System) (2019), Soil Series, http:// soil.rda.go.kr, (accessed 19.01.09).

Lee, C.H. and Kim, S.S. (1963) Explanatory text of the geological map of Hong song sheet $(1: 50,000)$. Geological survey of Korea, Korea, 33p

Lee, J.H., Jun, S.W., Lee, M.J. and Hong, H.J. (2010) Coupled Model Development between Groundwater Recharge Quantity and Climate Change in River Watershed II, Green Growth Research 2010-18, Korea Environment Institute, 149p.

MCT(Ministry of Construction and Transportation), K-water, KIGAM(Korea Institute of Geoscience and Mineral Resources) (2005) Report for basic groundwater survey of Hongseon area, $253 \mathrm{p}$.

ME(Ministry of Environment) and K-water (2019) 2019 Groundwater Annual Report, 372p.

MLT(Ministry of Land and Transport) (2017) National Groundwater Basic Plan (supplemented), 168p.

Neitsch, S.L., Arnold, J.G., Kiniry, J.R., Williams, J.R. and King, K.W. (2002) Soil and Water Assessment Tool: Theoretical documentation, Version 2000, TWRI Report TR-191. College Station, TX.: Texas Water Resources Institute.

Park, C.K. (1996) Estimation of the available amount of groundwater in south Korea: 2. Application of five major river basins. J. Soil Groundw. Environ. v.3(1), p.21-26.
Park, C., Lee, J. and Koo, M.-H. (2013) Development of a fullydistributed daily hydrologic feedback model addressing vegetation, land cover, and soil water dynamics (VELAS). Journal of Hydrology, v.493, p.43-56. doi: 10.1016/j.jhydrol.2013. 04.027

Park, E. (2012) Delineation of recharge rate from a hybrid water table fluctuation method. Water Resources Research, v.48, W07503, doi: 10.1029/2011WR011696.

Park J.-H. and Kang, B.-S. (2006) Comparison of runoff analysis between GIS-based distributed model and lumped model for flood forecast of dam watershed, Journal of the Korean Association of Geographic Information Studies, v.9(3), p.171182.

Park, J.-S., Kim, K.-H., Jeon, M.-W. and Kim, J.-S. (1999) Estimation methods of groundwater recharge rate in small basin. Journal of the Korean Society of Groundwater Environment, v.6(2), p.76-86.

Shin, E., Koh, E.-H., Ha, K., Lee, E. and Lee, K.-K. (2016) Impact of climate change on the groundwater recharge and groundwater level variations in Pyoseon watershed of Jeju island, Korea, Journal of the Korean Society of Groundwater Environment, v.21(6), p.22-35.

Vieux, B.E. (2004) Distributed Hydrologic Modeling Using GIS, second ed. Water Science Technology Series, v. 48. ISBN:1-40202459-2. Kluwer Academic Publishers, Norwell, Massachusetts, 289p.

Yoon, H., Yoon, P., Lee, E., Kim, G.B. and Moon, S.H. (2016) Application of machine learning technique-based time series models for prediction of groundwater level fluctuation to national groundwater monitoring network data. Journal of the Geological Society of Korea, v.52, p.187-199. 